J. Dairy Sci. 95:1222-1239

http://dx.doi.org/10.3168/jds.2011-4548

(C) American Dairy Science Association ${ }^{\circledR}$, 2012. Open access under CC BY-NC-ND license.

\title{
Effect of conjugated linoleic acid supplementation on body composition, body fat mobilization, protein accretion, and energy utilization in early lactation dairy cows
}

\author{
D. von Soosten, ${ }^{*}$ U. Meyer, ${ }^{*}$ M. Piechotta, $†$ G. Flachowsky, ${ }^{*}$ and S. Dänicke ${ }^{\star 1}$ \\ *Institute of Animal Nutrition, Friedrich-Loeffler-Institute (FLI), Federal Research Institute for Animal Health, Bundesallee 50, \\ 38116 Brunswick, Germany \\ †Clinic for Cattle, School of Veterinary Medicine Hanover, 30173 Hanover, Germany
}

\begin{abstract}
The objective of the study was to investigate the effects of trans-10,cis-12 and cis-9,trans-11 conjugated linoleic acid (CLA) supplementation on body composition, mobilization or accretion of body fat and protein mass, as well as the energy metabolism of dairy cows during the first $105 \mathrm{~d}$ in milk (DIM). For this purpose, a comparative slaughter experiment was conducted with 25 primiparous German Holstein cows. The experiment started at 1 DIM with the slaughter of 5 animals of an initial group receiving no CLA supplement. The remaining animals were fed a CLA supplement (n $=10)$ or a stearic acid-based control fat supplement $(\mathrm{CON} ; \mathrm{n}=10)$ from 1 DIM up to slaughter. After 42 DIM, 5 more cows from each treatment (42-CLA and 42 -CON) were slaughtered. The remaining 5 cows in each treatment were slaughtered after 105 DIM (105CLA and 105-CON). The animals of the CLA groups consumed $6.0 \mathrm{~g} / \mathrm{d}$ of trans-10, cis-12 CLA and $5.7 \mathrm{~g} / \mathrm{d}$ of cis-9,trans-11 CLA. During the slaughter process, the empty body mass was recorded and partitioned into 9 fractions (meat, bone, offal, hide, mammary gland, retroperitoneal fat, omental fat, mesenteric fat, and s.c. fat). The fractions were analyzed for dry matter, ether extract, crude protein, and ash to calculate the body composition of the empty body mass at the different slaughter times. The principle of the comparative slaughter technique was applied to estimate body fat or protein mobilization and accretion in the viewed periods from 1 DIM until 42 and 105 DIM. The heat production (HP) was calculated by subtracting the energy in milk and energy changes in body mass from the metabolizable energy intake. The body composition was not affected by CLA supplementation. However, the mobilization of body fat mass from 1 until 42 DIM was $24.1 \mathrm{~kg}$ in the $42-\mathrm{CON}$ group and $14.3 \mathrm{~kg}$ in the
\end{abstract}

Received May 18, 2011.

Accepted October 29, 2011.

${ }^{1}$ Corresponding author: Sven.Daenicke@fli.bund.de
42-CLA group. This resulted in a trend to lower body mass (fat and protein) mobilization of $10.5 \mathrm{~kg}$ in the 42-CLA group. Energy mobilization from body mass was $21.2 \mathrm{MJ} / \mathrm{d}$ in the $42-\mathrm{CON}$ and $11.5 \mathrm{MJ} / \mathrm{d}$ in the 42-CLA group. The HP was unchanged for the $42-\mathrm{CON}$ and 42-CLA group with 123.0 and $116.9 \mathrm{MJ} / \mathrm{d}$, respectively. From 1 until 105 DIM, the protein accretion was $4.3 \mathrm{~kg}$ and the daily energy retention in body protein was 1.0 MJ higher for CLA-supplemented cows. The HP was decreased in this period for the 105-CLA group $(115.5 \mathrm{MJ} / \mathrm{d})$ as compared with the $105-\mathrm{CON}$ group (125.9 MJ/d). Overall, the trend for a decreased body mass mobilization suggested a protective effect of CLA supplementation against excessive use of body reserves within 42 DIM. Continuous CLA supplementation until 105 DIM increased protein accretion. The effects on body mass mobilization and protein accretion in combination with the decreased HP in the CLA-fed cows suggested a more efficient utilization of metabolizable energy in CLA-supplemented early lactation dairy cows.

Key words: conjugated linoleic acid, body composition, dairy cow, energy metabolism

\section{INTRODUCTION}

In the physiological stage of early lactation, the available ME from DMI is not sufficient to satisfy the energy requirements of the dairy cow. The demands for milk energy $\left(\mathbf{E}_{\mathbf{L}}\right)$ and maintenance $\left(\mathbf{E}_{\mathbf{M}}\right)$ exceed the available ME from feed intake. Therefore, the dairy cow mobilizes energy from body mass $\left(\mathbf{E}_{\mathrm{G}}\right)$ to provide the required energy for $\mathrm{E}_{\mathrm{L}}$ (Bauman and Currie, 1980; Wenk et al., 2001). The synthesized milk fat represents about $50 \%$ of the $\mathrm{E}_{\mathrm{L}}$ (Tyrrell and Reid, 1965) and is the major reason for the high energy demands in early lactation and, consequently, for mobilization of $\mathrm{E}_{\mathrm{G}}$, mainly in the form of body fat. Conjugated linoleic acid (CLA), especially the trans-10,cis-12 isomer, affected the energy metabolism of the lactating dairy cow by inducing milk fat depression, manifested as inhibition 
of milk fat synthesis (Baumgard et al., 2000). However, in energy limitation situations it appears that the dairy cow expends the spared milk fat energy for higher milk yield (Bernal-Santos et al., 2003; de Veth et al., 2006). This effect was also observed for animals used in the present study and published in our previous work (von Soosten et al., 2011). Furthermore, CLA supplementation influences fat metabolism in ruminants, not only in the mammary gland, by inhibiting milk fat synthesis. For the cis-9,trans-11 and trans-10,cis-12 CLA-supplemented dairy cows of the present study, a trend was observed to a decelerated reduction of the retroperitoneal adipose depot mass within 42 DIM (von Soosten et al., 2011). Conversely, in the same animals, Akter et al. (2011) measured adipose cell size of different adipose tissues and concluded lipolytic or antilipogenic effects in CLA-fed animals. In general, performance studies with lactating dairy cows investigate the effect of combined cis-9,trans-11 and trans-10,cis-12 CLA supplementation on fat and energy metabolisms by using changes of BW, BCS, or back fat thickness (BFT) and the blood plasma NEFA concentration or the calculated energy balance as indicators for mobilization of body reserves. Odens et al. (2007) showed that CLA-fed cows lost less body condition in early lactation and a decreased BW loss was observed for one CLA group. Blood plasma NEFA concentration was decreased and an improved energy balance was observed. However, often no effect of CLA was observed on BW, BCS, plasma NEFA concentration, and energy balance (Bernal-Santos et al., 2003; Castañeda-Gutiérrez et al., 2007) or BFT (Pappritz et al., 2011). In lactating ewes, Sinclair et al. (2010) found that BFT determined between the tenth and eleventh thoracic vertebrae was reduced, between the fifth and sixth lumbar vertebrae was not changed, and variables of body composition (body fat, body protein, and body energy content) were not altered after CLA supplementation for $10 \mathrm{wk}$. Overall, none of the studies quantified the changes in body fat over the CLA treatment period. Also, adequate evaluation for the mobilization of body reserves in early lactation using the change of $\mathrm{BW}$ is confounded by variation in DMI. The overlap of these processes conceals the mobilization of body reserves, and additionally, water deposition could replace the mobilized body fat (Moe et al., 1971). Furthermore, with the change of BW, BCS, and $\mathrm{BFT}$, it is not possible to differentiate fat and protein mobilization or accretion. Using this general approach, performance trials with CLA supplementation of dairy cow rations in early lactation pointed out that further research in this field of energy utilization and repartitioning of body reserves is needed if CLA is fed in early lactation (Bernal-Santos et al., 2003; Odens et al., 2007; Sinclair et al., 2010). For this purpose, the comparative slaughter technique offers the opportunity to determine the mobilization and accretion of body fat and protein mass over a longer period (Lofgreen and Otagaki, 1960; Bath et al., 1965).

Besides CLA effects on fat metabolism, less is known about CLA effects on protein metabolism in the dairy cow. The CLA effects on daily milk protein synthesis in dairy cows are inconsistent; most studies observed no effect on milk protein yield (e.g., Odens et al., 2006; Pappritz et al., 2011; von Soosten et al., 2011), whereby in studies by de Veth et al. (2006) and Medeiros et al. (2010), CLA-fed cows with restricted energy supply showed an increased milk protein yield. Additionally, for nutrient partitioning and growth in dairy cows, the somatotropic axis, with IGF-I as a key mediator, plays an important role (Lucy et al., 2001), and Baumgard et al. (2000) showed that after abomasal infusion of the cis-9,trans-11 isomer, IGF-I blood plasma concentrations were slightly higher, whereby the trans-10, cis-12 isomer had no effect.

Overall, these aspects of CLA effects on energy, fat, and protein metabolism are not well investigated in dairy cows. The objective of the present study was to investigate the effect of cis-9,trans-11 and trans10, cis-12 CLA supplementation on energy metabolism and energy partitioning with special regard to body fat and protein mobilization and accretion from calving up to 105 DIM by using the comparative slaughter technique.

\section{MATERIALS AND METHODS}

\section{Animals, Experimental Design, and Feeding}

The study was conducted at the experimental station of the Institute of Animal Nutrition, Friedrich-LoefflerInstitute (FLI), Brunswick, Germany, in compliance with the European Union Guidelines concerning the protection of experimental animals. Authorization for this experiment was given by the Lower Saxony State Office for Consumer Protection and Food Safety (LAVES), Oldenburg, Germany (File Number 33.11.42502-04-071/07). The whole experiment is described in full detail by von Soosten et al. (2011). In brief, primiparous lactating German Holstein cows were slaughtered after 1, 42, and 105 DIM. Twentyfive animals were assigned to 5 groups with 5 animals in each group. First, an initial group (IG), receiving no CLA supplement, was slaughtered at 1 DIM. The remaining 20 animals were allocated to 1 of 2 feeding treatments (10 animals in each treatment), receiving a control (CON treatment) or CLA-supplemented (CLA treatment) diet, beginning at calving and ceasing at experimental slaughter. After 42 DIM, 5 animals 
VON SOOSTEN ET AL.

Table 1. Ingredients and chemical composition of the concentrates and partial mixed ration $(\mathrm{PMR})^{1}$

\begin{tabular}{|c|c|c|c|c|}
\hline \multirow[b]{2}{*}{ Composition } & \multicolumn{3}{|c|}{ Concentrate $^{2}$} & \multirow[b]{2}{*}{ PMR } \\
\hline & $\mathrm{CON}$ & CLA & PMR & \\
\hline \multicolumn{5}{|l|}{ Ingredient (\%) } \\
\hline Wheat grain & 39.5 & 39.5 & 41 & \\
\hline Sugar beet pulp, dried & 29 & 29 & 30 & \\
\hline Rapeseed meal & 20 & 20 & 20 & \\
\hline Soybean meal & 6.5 & 6.5 & 6.5 & \\
\hline Vitamin/mineral premix ${ }^{3}$ & 2 & 2 & 2 & \\
\hline Control fat supplement & 2.5 & & & \\
\hline CLA supplement & & 2.5 & & \\
\hline Calcium carbonate & 0.5 & 0.5 & 0.5 & \\
\hline \multicolumn{5}{|l|}{ Analyzed chemical profile } \\
\hline $\mathrm{DM}(\mathrm{g} / \mathrm{kg})$ & 873 & 871 & 870 & 445 \\
\hline \multicolumn{5}{|l|}{ Nutrients $(\mathrm{g} / \mathrm{kg}$ of $\mathrm{DM})$} \\
\hline Crude ash & 65 & 69 & 64 & 62 \\
\hline $\mathrm{CP}$ & 182 & 180 & 182 & 124 \\
\hline Ether extract & 50 & 44 & 20 & 28 \\
\hline $\mathrm{ADF}$ & 134 & 133 & 134 & 208 \\
\hline NDF & 259 & 260 & 265 & 405 \\
\hline \multicolumn{5}{|l|}{ Energy $^{4}(\mathrm{MJ} / \mathrm{kg}$ of DM $)$} \\
\hline ME & 13.9 & 13.7 & 13.5 & 11.9 \\
\hline $\mathrm{NE}_{\mathrm{L}}$ & 8.9 & 8.7 & 8.7 & 7.5 \\
\hline \multicolumn{5}{|l|}{$\mathrm{CLA}^{\mathrm{L}}(\mathrm{g} / \mathrm{kg}$ of $\mathrm{DM})$} \\
\hline $\mathrm{C} 18: 2$ trans-10,cis-12 & 0.0 & 1.7 & 0.0 & 0.0 \\
\hline C18:2 cis-9,trans-11 & 0.0 & 1.6 & 0.0 & 0.0 \\
\hline
\end{tabular}

${ }^{1}$ Partial mixed ration $=38 \%$ corn silage, $25 \%$ grass silage, and $37 \%$ PMR-concentrate on DM basis.

${ }^{2} \mathrm{CON}=$ control; CLA $=$ conjugated linoleic acid

${ }^{3}$ Per kilogram of mineral feed: $140 \mathrm{~g}$ of Ca; $120 \mathrm{~g}$ of Na; $70 \mathrm{~g}$ of P; $40 \mathrm{~g}$ of Mg; $6 \mathrm{~g}$ of Zn; $5.4 \mathrm{~g}$ of Mn; $1 \mathrm{~g}$ of $\mathrm{Cu} ; 100 \mathrm{mg}$ of I; $40 \mathrm{mg}$ of Se; $5 \mathrm{mg}$ of Co; 1,000,000 IU of vitamin A; 100,000 IU of vitamin $\mathrm{D}_{3}$; and 1,500 mg of vitamin E.

${ }^{4}$ Calculation based on nutrient digestibilities measured with wethers (GfE, 1991).

of the CON treatment (42-CON), and 5 animals of the CLA treatment (42-CLA), were slaughtered. The remaining 5 animals of the CON $(\mathbf{1 0 5}-\mathbf{C O N})$ and CLA (105-CLA) treatment were slaughtered after 105 DIM. The control fat supplement (Silafat; BASF SE, Ludwigshafen, Germany) or the rumen-protected CLA supplement (Lutrell Pure; BASF SE) was mixed into the concentrate, which was provided by a computerized concentrate feeding station $(3.5 \mathrm{~kg} / \mathrm{d}$ on a DM basis). The animals of the CLA groups consumed 6.0 $\mathrm{g} / \mathrm{d}$ of the trans-10,cis-12 CLA isomer and $5.7 \mathrm{~g} / \mathrm{d}$ of the cis-9,trans-11 CLA isomer (calculated based on the analyzed proportion in concentrates). In the control fat supplement, these isomers were substituted by stearic acid. Together with the feeding of the different supplemented concentrates, all animals received a partial mixed ration, comprising $38 \%$ corn silage (Zea mays), $25 \%$ grass silage, and $37 \%$ concentrate (on a DM basis) for ad libitum intake from calving to slaughter (Table 1). The average milk yield (mean $\pm \mathrm{SE}$ ) for the 42 -CON and 42-CLA cows from 1 to 42 DIM was $24.5 \pm 0.8$ and $24.7 \pm 0.9 \mathrm{~kg} / \mathrm{d}$, respectively. Milk fat content averaged $4.4 \pm 0.1 \%$ for the $42-\mathrm{CON}$ and $3.6 \% \pm 0.2$ for the 42 CLA group. From 1 to 105 DIM for the $105-\mathrm{CON}$ and 105-CLA groups, the milk yield averaged $24.4 \pm 0.5$ and $27.2 \pm 0.5 \mathrm{~kg} / \mathrm{d}$, respectively. The milk fat content was $4.2 \pm 0.1 \%$ for the 105 -CON group and $3.3 \pm 0.1 \%$ for the 105-CLA group.

\section{Measurements, Slaughter, and Sample Collection}

The daily individual feed intake was recorded from calving to slaughter. Samples of the partial mixed ration were collected 4 times per week directly after feeding and pooled over approximately 4 wk. Samples of the concentrates were taken once per week and composited monthly. Milking took place 2 times daily at 0530 and $1530 \mathrm{~h}$. Milk yield was recorded using automatic milk counters and BW was automatically recorded when leaving the milking parlor. Milk samples were taken twice per week and stored at $4^{\circ} \mathrm{C}$ until analysis. At 1 , $7,14,21$, and 28 DIM, and immediately before slaughter, blood samples were drawn from the vena jugularis. Furthermore BCS was recorded using a 5-point scale (Edmonson et al., 1989) and BFT was determined by applying ultrasound (Staufenbiel, 1997) immediately before slaughter.

The slaughter took place in the slaughter facilities at the experimental station of the Institute of Animal Nutrition, FLI, next to the pens of the animals. After the 
morning milking the cow was transported to the slaughter facilities, weighed, stunned with a captive bolt gun, and exsanguinated. Blood was collected and weighed. Body parts were weighed as they were dissected from the animal and assigned to the 9 different fractions named as meat, bones, hide, offal, mammary gland, retroperitoneal fat, mesenteric fat, omental fat, and s.c. fat. The head, mammary gland, tail, and feet (below the carpal joint or hock) were detached first. The eyes and tongue were removed from the head, which was separated in 2 halves and the brain was removed. Claws were sawed off, weighed, and rejected. The full gastrointestinal tract, urinary tract, and gall bladder were removed. The hide, heart, lung, liver, kidneys, uterus, spleen, thyroid gland, thymus, and retroperitoneal fat were dissected and weighed during the slaughter process. After separation of the gastrointestinal tract into reticulorumen, omasum and abomasum, and intestine, these parts were weighed full before, and empty after, opening and cleaning of digests. Mesenteric fat adhering to the intestine and the omental fat, which included fat from the reticulorumen, omasum and abomasum, were cut off and weighed. The gastrointestinal tract fill was calculated as the difference in weights of the full and cleaned gastrointestinal tract. The carcass was divided longitudinally into 2 symmetric parts, weighed and stored at $4^{\circ} \mathrm{C}$. The offal fraction consisted of the organs, tongue, eyes, brain, empty gastrointestinal tract, and blood. Immediately after slaughter the offal, mammary gland, retroperitoneal fat, mesenteric fat, and omental fat fraction were homogenized by chopping 25 rounds per sample using a meat cutter. Two representative samples were taken and stored at $-21^{\circ} \mathrm{C}$ until analysis. The hide was divided along the wither in 2 symmetric parts and the left part of the hide was first manually reduced to small pieces and then homogenized by the meat cutter (30 rounds) and sampled and stored at $-21^{\circ} \mathrm{C}$ till analysis. The next day, carcass parts and the halves of the head were weighed once again for determination of water loss. Subcutaneous fat was dissected manually with a knife from the left carcass and weighed. The whole s.c. fat mass was calculated by multiplying the mass of the left part of the s.c. fat depot, with the quotient resulting from weight of both carcass parts and weight of the left carcass. The meat from the left carcass, left side of the head, left feet (meat was assigned to the meat of the carcass), and whole tail was also separated from the bones manually with a knife and weighed. The s.c. fat and meat fraction were homogenized by the meat cutter ( 25 rounds) and duplicate samples were taken. The bones were weighed and stored at $-21^{\circ} \mathrm{C}$ until sawed in small pieces and homogenized in a bone mill.

\section{Chemical Analyses}

The composition of the feedstuffs (DM, crude ash, $\mathrm{CP}$, ether extract, NDF, and ADF) was determined according to the methods of the Association of German Agricultural Analysis and Research Centers (VDLUFA, 1993). The analysis of fatty acid profile of fat supplements and feedstuffs is described elsewhere (von Soosten et al., 2011). Milk samples were analyzed for fat, protein, and lactose using an infrared milk analyzer (Milkoscan FT 6000 combined with a Fossomatic 5000; Foss Electric A/S, Hillerød, Denmark). Blood samples were analyzed for plasma concentrations of IGF-I in duplicate by a commercially available 2-site-immunoradiometric assay (IRMA, DSL-5600 Active IGF-I-IRMA; Diagnostic Systems Laboratories Inc., Webster, TX). Insulin-like growth factor I was separated from its binding proteins by an acid-ethanol extraction procedure, as described by the manufacturer and previously published (Lee and Henricks, 1990; Taylor et al., 2004; Sander et al., 2011). The assay was tested for bovine plasma by determining the recovery and intra- and interassay coefficient of variation. The recovery was tested by adding $200 \mathrm{ng} /$ $\mathrm{mL}$ of IGF-I [obtained from the National Hormone and Peptide Program (NHPP), National Institute of Diabetes and Digestive and Kidney Diseases (NIDDK), and A. F. Parlow] to 5 bovine plasma samples. Afterward, the acid-ethanol extraction and IRMA was performed according to instructions from the manufacturer. The recovery ranged between 96 and $112 \%$. The intra-assay coefficient of variation was 1.5 to $3.5 \%$ and the interassay coefficient of variation was 1.5 to $8.5 \%$.

Samples of the meat, bone, offal, mammary gland, retroperitoneal fat, mesenteric fat, omental fat, and s.c. fat fraction were thawed and dried by lyophilization for determination of DM content. Afterward, the samples were homogenized once again using a meat cutter. Exclusively, the hide fraction was dried at $60^{\circ} \mathrm{C}$ in a forced-air oven for $3 \mathrm{~d}$ and additionally homogenized with a mill (equipped with a $1-\mathrm{mm}$ sieve). For exact DM determination of all fractions, the remaining moisture was determined in a drying cabinet at $103^{\circ} \mathrm{C}$. Crude ash, CP, and ether extract were analyzed according to the methods of the Association of German Agricultural Analysis and Research Centers (VDLUFA, 1993). Crude ash was determined by differential weighing before and after combustion in a muffle oven at $550^{\circ} \mathrm{C}$ for $5 \mathrm{~h}$. For determination of ether extract, samples were extracted with petrol ether and the Kjeldahl method was applied to determine CP content. All fraction samples were analyzed for crude ash, CP, and ether extract in triplicate and the average was taken for calculation of the fraction composition. 


\section{Calculations}

The empty body mass (EBM) is defined as the whole body of the cow without claws cut off, digesta, and content of the urinary and gall bladder, and was calculated as the sum of all body part weights, which were recorded during the slaughter process. The mass of the meat fraction of the whole animal was the sum of meat mass from head, carcass, and tail. The meat mass from the head was calculated by multiplying the meat mass of the left side of the head with the quotient resulting from the mass of both head parts and mass of the left part of the head. The meat mass from the carcass was calculated by multiplying the meat mass of the left carcass with the quotient resulting from mass of both carcass parts and left carcass. The bone mass from the carcass was calculated by multiplying the bone mass from the left carcass with the similar quotient used for calculation of the meat mass. The bone mass from the head was calculated by multiplying the bone mass of the left side of the head with the quotient resulting from the mass of both head parts and mass of the left part of the head. The mass of the bone fraction was calculated as the sum of the bone mass from the head, carcass, and tail. The body composition, including water, ether extract, $\mathrm{CP}$, and crude ash was calculated by adding the contents of the fractions together. The fat-free DM (FFDM) was calculated as the sum of CP and ash content in the EBM.

Applying the principles of the comparative slaughter technique (Bath et al., 1965) by assuming that the average EBM and average body composition of the initial slaughter group represented the EBM and body composition of the animals in the remaining 4 groups at 1 DIM, the average EBM and body composition of the IG served for calculation of the body composition at 1 DIM for the animals slaughtered after 42 or 105 DIM. The average body composition of the corresponding 42CON and 42-CLA groups served for the calculation of the body composition of the 105-CON and 105-CLA groups at 42 DIM. The obtained body composition at 42 DIM for the animals actually slaughtered on 105 DIM was used to calculate the body fat and protein mobilization and accretion from 42 to 105 DIM. The body mass (fat or protein) mobilization and accretion was the difference of body mass at the end minus the calculated body mass at the start of the viewed periods from 1 to 42 DIM, from 1 to 105 DIM, and from 42 to 105 DIM. The changes in BW were calculated by subtracting the BW of the animal at the start of a viewed period from the $\mathrm{BW}$ at the end of this period. The area under the curve (AUC) for weekly average BW data was calculated by using the trapezoidal rule (Jones, 1997) to obtain additional information about the change of BW from all BW data. Lower values for AUC indicated an intensified decrease in BW. The EBM change and the fat and protein mobilization and accretion in the meat fraction were calculated with the same methods as for body mass mobilization and accretion.

The fat and protein mobilization and accretion from 1 DIM to slaughter were transformed to the corresponding energy equivalents by using the gross energy concentration of $39.8 \mathrm{~kJ} / \mathrm{g}$ for fat and $23.8 \mathrm{~kJ} / \mathrm{g}$ for protein, respectively (Brouwer, 1965). The daily mobilized and accreted energy in the form of body mass $\left[\mathrm{E}_{\mathrm{G}}(\mathrm{MJ} / \mathrm{d})\right]$ was calculated by dividing the mobilized and accreted energy from 1 DIM to slaughter by the number of days from 1 DIM to slaughter.

Based on the equations published by the Gesellschaft für Ernährungsphysiologie (GfE; GfE, 2001) the $\mathrm{E}_{\mathrm{L}}$ was calculated using the following equation:

$$
\begin{aligned}
& \mathrm{E}_{\mathrm{L}}(\mathrm{MJ} / \mathrm{kg})=0.38 \times \text { milk fat }(\%) \\
& +0.21 \times \text { milk protein }(\%)+0.95 .
\end{aligned}
$$

The weekly mean of $\mathrm{E}_{\mathrm{L}} / \mathrm{d}$ (calculated with measurements on daily milk yield and milk fat and milk protein content twice per week) was multiplied by 7 to obtain the weekly $\mathrm{E}_{\mathrm{L}}$. Then, the weekly $\mathrm{E}_{\mathrm{L}}$ was cumulated over the period and divided by the number of days in this period to calculate an average value for daily $\mathrm{E}_{\mathrm{L}}$.

The daily ME intake (MEI) was cumulated over the period divided by the number of days in this period to obtain an average daily value for MEI.

The heat production (HP) was calculated using Equation 2:

$$
\begin{aligned}
\operatorname{HP}(\mathrm{MJ} / \mathrm{d})= & \operatorname{MEI}(\mathrm{MJ} / \mathrm{d})-\left[\mathrm{E}_{\mathrm{L}}(\mathrm{MJ} / \mathrm{d})\right. \\
& \left.+\mathrm{E}_{\mathrm{G}}(\mathrm{MJ} / \mathrm{d})\right] .
\end{aligned}
$$

For calculation of the energy efficiency (EE) according to (Weiss et al., 2008), during times of mobilization or accretion of body mass, the requirements for maintenance $\mathrm{NE}_{\mathrm{M}}$ and lactation $\mathrm{NE}_{\mathrm{L}}$ are needed and their estimation is described elsewhere (von Soosten et al., 2011). The daily requirements for $\mathrm{NE}_{\mathrm{M}}$ and $\mathrm{NE}_{\mathrm{L}}$ were cumulated from 1 DIM up to slaughter. In the case of body mass mobilization, $\mathrm{E}_{\mathrm{G}}$ was multiplied by the factor 0.84 in considering that the mobilized energy from body mass is converted into $\mathrm{E}_{\mathrm{L}}$ at a proportion of $84 \%$ (Moe et al., 1971). Afterward, this value was subtracted from $\mathrm{NE}_{\mathrm{M}}$ and $\mathrm{NE}_{\mathrm{L}}$ (Equation 3). In the case of body mass accretion, $\mathrm{E}_{\mathrm{G}}$ was added to $\mathrm{NE}_{\mathrm{M}}$ and $\mathrm{NE}_{\mathrm{L}}$ (Equation 4). The result of adding or subtracting $\mathrm{NE}_{\mathrm{M}}, \mathrm{NE}_{\mathrm{L}}$, and $\mathrm{E}_{\mathrm{G}}$ was divided by the DMI (Equation 3 and 4). The following equations were used: 
During times of mobilization of body mass,

$\mathrm{EE}\left(\mathrm{MJ}\right.$ of $\mathrm{NE}_{\mathrm{L}} / \mathrm{kg}$ of $\left.\mathrm{DMI}\right)=\left\{\mathrm{NE}_{\mathrm{M}}\left(\mathrm{MJ}\right.\right.$ of $\left.\mathrm{NE}_{\mathrm{L}}\right)+$

$\mathrm{NE}_{\mathrm{L}}\left(\mathrm{MJ}\right.$ of $\left.\left.\mathrm{NE}_{\mathrm{L}}\right)-\left[\mathrm{E}_{\mathrm{G}}(\mathrm{MJ}) \times 0.84\right]\right\} / \mathrm{DMI}(\mathrm{kg})$.

During times of accretion of body mass,

$$
\begin{gathered}
\mathrm{EE}\left(\mathrm{MJ} \text { of } \mathrm{NE}_{\mathrm{L}} / \mathrm{kg} \text { of } \mathrm{DMI}\right)=\left[\mathrm{NE}_{\mathrm{M}}\left(\mathrm{MJ} \text { of } \mathrm{NE}_{\mathrm{L}}\right)\right. \\
\left.+\mathrm{NE}_{\mathrm{L}}\left(\mathrm{MJ} \text { of } \mathrm{NE}_{\mathrm{L}}\right)+\mathrm{E}_{\mathrm{G}}(\mathrm{MJ})\right] / \mathrm{DMI}(\mathrm{kg}) .
\end{gathered}
$$

The energy partitioning of the MEI into HP, $\mathrm{E}_{\mathrm{L}}$, and $\mathrm{E}_{\mathrm{G}}$ was calculated as an average of all animals, and separately for the CON and CLA groups, during the different periods of the experiment.

\section{Statistical Analyses}

All statistical analyses were carried out using the software SAS version 9.1 (SAS Institute, 2004). Data for all variables were tested for normal distribution with the Kolmogorov-Smirnov test and for homogeneity of variances with the Levene test. Variables of body composition and the 9 fractions were analyzed using the GLM procedure. The CON and CLA groups at the 42 and 105 DIM slaughter were compared with the IG by using the Dunnett test. For data of the CON and CLA groups at the 42 and 105 DIM slaughter without the IG, the GLM procedure was used with treatment (CON or CLA), DIM (42 or 105), and interactions of treatment $\times$ DIM as the fixed effects.

The IGF-I plasma concentrations were analyzed as repeated measures using the MIXED procedure of SAS. An autoregressive covariance structure was modeled using week of lactation as the repeated effect (Littell et al., 1998). The model contained treatment and week of lactation as the fixed effects. Cows were treated as random effect.

The mobilization and accretion of body mass and energy from 1 to 42 or 105 DIM and from 42 to 105 DIM for the CON and CLA groups were analyzed by using the TTEST procedure. The variables HP, MEI, $\mathrm{E}_{\mathrm{L}}$, energy efficiency, proportion of energy variables on MEI, the changes of BW and EBM, as well as the AUC of $\mathrm{BW}$ data, were analyzed using the same procedure.

The BCS and BFT measured at the day of slaughter were correlated with total mass and fat mass of the empty body and the 9 fractions. The body fat mobilization in the different periods was correlated with the average value in the respective period of plasma NEFA or net energy balance data, which were obtained from our previous study (von Soosten et al., 2011). Pearson correlation coefficients were calculated by using the CORR procedure of SAS.
For all analyses, significance was declared when $P$ values were $<0.05$ and a tendency was noted when 0.05 $<P<0.10$.

\section{RESULTS}

The BW recorded at the start of the experiment (1 DIM) showed that animals were representative in each group. The average BW at 1 DIM (means \pm SE) was $521 \pm 15 \mathrm{~kg}$ for the IG, $515 \pm 13 \mathrm{~kg}$ for the 42 -CON group, $512 \pm 24 \mathrm{~kg}$ for the 42-CLA group, $512 \pm 16$ $\mathrm{kg}$ for the 105-CON group, and $496 \pm 11 \mathrm{~kg}$ for the 105-CLA group.

\section{Body Composition}

The mean body composition of the 5 groups slaughtered at 3 different time points after calving and fed no fat supplement and the CLA supplement or the control fat supplement are presented in Table 2. Overall, CLA effects on body composition were not detectable. The EBM was not affected by CLA feeding or slaughter at different DIM. The water content of EBM presented as total mass of the animals slaughtered at 105 DIM was increased compared with the groups slaughtered at 42 DIM. However, expressed as proportion of EBM, this effect was not detectable and, consequently, the DM was not affected by CLA treatment or slaughter at different DIM. Ether extract, CP, ash, and FFDM shown as percentage of DM were not influenced by CLA treatment or slaughter time. Additionally, ether extract, ash, and FFDM shown as total mass or proportion of EBW remained unchanged. The CP content was not affected when expressed as total mass. Presented as proportion of EBM, CP showed a trend for an influence of CLA treatment $(P=0.062)$. The difference between DM mass and the sum of ether extract, CP, and ash mass could be explained as due to carbohydrates (less than $0.5 \%$ according to Reid et al. (1955)) in the body of the animal, which were not determined. The energy contents of the EBM were not different. The BCS and BFT were not affected by CLA treatment. However, compared with the IG, BCS tended to be deceased for the 105-CLA group. For BFT, the 42-CON and 105-CLA groups were decreased compared with the IG, whereas the 42-CLA group showed a trend for a decreased BFT.

\section{Composition of the Tissue Fractions}

The compositions of the meat, bone, offal, hide, and mammary gland fraction are shown in Table 3. Overall, no CLA effects were found on the composition of these fractions. The total mass of the meat fraction in the 
Table 2. Empty body mass (EBM), chemical composition, energy content of EBM, BCS, and back fat thickness (BFT; means) of cows slaughtered at different time points and fed no fat supplement (initial group, IG), the control (CON) diet, or conjugated linoleic acid (CLA)supplemented diet

\begin{tabular}{|c|c|c|c|c|c|c|c|c|c|}
\hline Variable & $\begin{array}{c}\mathrm{IG}^{1} \\
(\mathrm{n}=5)\end{array}$ & \multicolumn{4}{|c|}{ Treatment $^{2}$} & $\mathrm{SEM}^{3}$ & \multicolumn{3}{|c|}{$P$-value ${ }^{4}$} \\
\hline EBM (kg) & $447.1 \pm 11.9$ & 397.5 & 402.3 & 434.1 & 412.7 & 15.6 & 0.600 & 0.152 & 0.411 \\
\hline \multicolumn{10}{|l|}{ Water } \\
\hline Mass $(\mathrm{kg})$ & $266.5 \pm 7.8$ & 246.9 & 241.7 & 263.4 & 259.0 & 7.3 & 0.514 & 0.034 & 0.957 \\
\hline Mass (kg) & $180.6 \pm 7.6$ & 150.6 & 160.6 & 170.7 & 153.7 & 10.1 & 0.734 & 0.523 & 0.197 \\
\hline$\%$ of EBM & $40.4 \pm 1.1$ & 37.9 & 39.8 & 39.2 & 37.1 & 1.2 & 0.943 & 0.547 & 0.109 \\
\hline \multicolumn{10}{|l|}{ Ether extract } \\
\hline Mass (kg) & $87.0 \pm 7.1$ & 61.1 & 70.5 & 75.7 & 60.8 & 8.5 & 0.746 & 0.775 & 0.173 \\
\hline$\%$ of EBM & $19.4 \pm 1.2$ & 15.4 & 17.3 & 17.2 & 14.5 & 1.6 & 0.813 & 0.765 & 0.151 \\
\hline$\%$ of DM & $47.9 \pm 1.9$ & 40.4 & 43.2 & 43.5 & 38.8 & 2.8 & 0.740 & 0.808 & 0.200 \\
\hline \multicolumn{10}{|l|}{$\mathrm{CP}$} \\
\hline$\%$ of EBM & $4.6 \pm 0.1$ & 5.1 & 5.1 & 4.9 & 4.9 & 0.2 & 0.909 & 0.257 & 0.775 \\
\hline$\%$ of DM & $11.5 \pm 0.4$ & 13.6 & 12.8 & 12.6 & 13.4 & 0.7 & 0.975 & 0.764 & 0.272 \\
\hline \multicolumn{10}{|l|}{ FFDM $^{5}$} \\
\hline Mass (kg) & $91.4 \pm 1.3$ & 85.8 & 87.2 & 88.9 & 89.0 & 2.4 & 0.762 & 0.342 & 0.793 \\
\hline$\%$ of EBM & $20.5 \pm 0.4$ & 21.6 & 21.7 & 20.5 & 21.6 & 0.4 & 0.170 & 0.176 & 0.249 \\
\hline$\%$ of DM & $50.9 \pm 1.9$ & 57.2 & 54.9 & 52.8 & 58.7 & 2.6 & 0.493 & 0.913 & 0.130 \\
\hline \multicolumn{10}{|l|}{ Energy } \\
\hline EBM (MJ) & $5,142.9 \pm 283.1$ & 3,991.0 & $4,394.0$ & $4,622.8$ & $4,055.8$ & 364.3 & 0.825 & 0.692 & 0.202 \\
\hline $\mathrm{DM}(\mathrm{MJ} / \mathrm{kg})$ & $28.4 \pm 0.4$ & 26.5 & 27.2 & 26.8 & 26.3 & 0.6 & 0.916 & 0.662 & 0.326 \\
\hline EBM (MJ/kg) & $11.5 \pm 0.4$ & 10.0 & 10.9 & 10.6 & 9.7 & 0.6 & 0.994 & 0.616 & 0.162 \\
\hline BCS & $3.05 \pm 0.05$ & 2.90 & 3.00 & 3.05 & $2.85 \dagger$ & 0.08 & 0.515 & 1.000 & 0.063 \\
\hline BFT (cm) & $2.84 \pm 0.04$ & $2.26^{* *}$ & $2.45 \dagger$ & 2.53 & $2.26^{* *}$ & 0.13 & 0.778 & 0.778 & 0.105 \\
\hline
\end{tabular}

${ }^{1}$ Mean \pm SE of cows slaughtered at 1 DIM (served to calculate baseline values for calculation of body fat and protein mobilization and accretion by using the principle of the comparative slaughter technique). Cows of the IG received no fat supplement and no CLA.

${ }^{2}$ Treatment: cows of the CLA groups consumed $6 \mathrm{~g} / \mathrm{d}$ of trans-10,cis-12 CLA and $6 \mathrm{~g} / \mathrm{d}$ of cis-9,trans-11 CLA. Cows of the CON groups received a control fat supplement in which the CLA were substituted by stearic acid.

${ }^{3}$ Pooled SEM included data from the CON and CLA groups slaughtered at 42 and 105 DIM without the IG.

${ }^{4}$ Statistical analyses with the GLM procedure included data from the CON and CLA groups slaughtered at 42 and 105 DIM without the IG. $P$-values in the CLA and DIM columns are related to the fixed effects of CLA supplementation and slaughter time at different DIM, respectively. $P$-values in the CLA $\times$ DIM column describe the interactions between the fixed effects.

${ }^{5}$ Fat-free DM (sum of CP and ash).

$\dagger$ Indicates that means tended to be significantly different $(0.05<P<0.10)$ from those of the IG (Dunnett test); ** indicates that means are significantly different from those of the IG (Dunnett test; $P<0.01$ ).

groups slaughtered at 42 DIM tended to be decreased compared with the IG and were increased for the animals slaughtered at 105 DIM. The other variables for the meat fraction (ether extract, $\mathrm{CP}$, ash, energy in $\mathrm{MJ} /$ $\mathrm{kg}$, and proportion of empty body energy) remained unchanged. The proportion of empty body energy of the meat fraction amounted to approximately half of the total empty body energy (average across all groups $45.3 \%)$.

Apart from DM and CP content, the bone fraction was not influenced by the different treatments. The CP content was lower at 105 DIM in the CON and CLA group. The interaction between CLA and DIM for bone $\mathrm{DM}$ is due to a low value for the 42 -CON group.
The ash contents of the offal fraction for the $42-\mathrm{CON}$ and 105-CLA groups were higher than for the IG. Additionally, the energy value per kilogram was decreased in all groups compared with the IG. The proportion of empty body energy showed interactions between CLA treatment and DIM. The hide fraction did not differ in any of the presented variables. The total mass of the mammary gland fraction in the 42 -CON group tended to be decreased and in the 42-CLA, 105-CON, and 105-CLA group was decreased compared with the IG. Furthermore, the slaughter at different DIM affected the $\mathrm{CP}$ content and the proportion of mammary gland energy content of the total empty body energy. The sum of the percentage of ether extract, CP, and ash is 
Table 3. Total mass, DM, chemical composition of DM, and energy content (means) in the meat, bone, offal, hide, and mammary gland fraction of cows slaughtered at different time points and fed no fat supplement (initial group, IG), the control (CON) diet, or conjugated linoleic acid (CLA)-supplemented diet

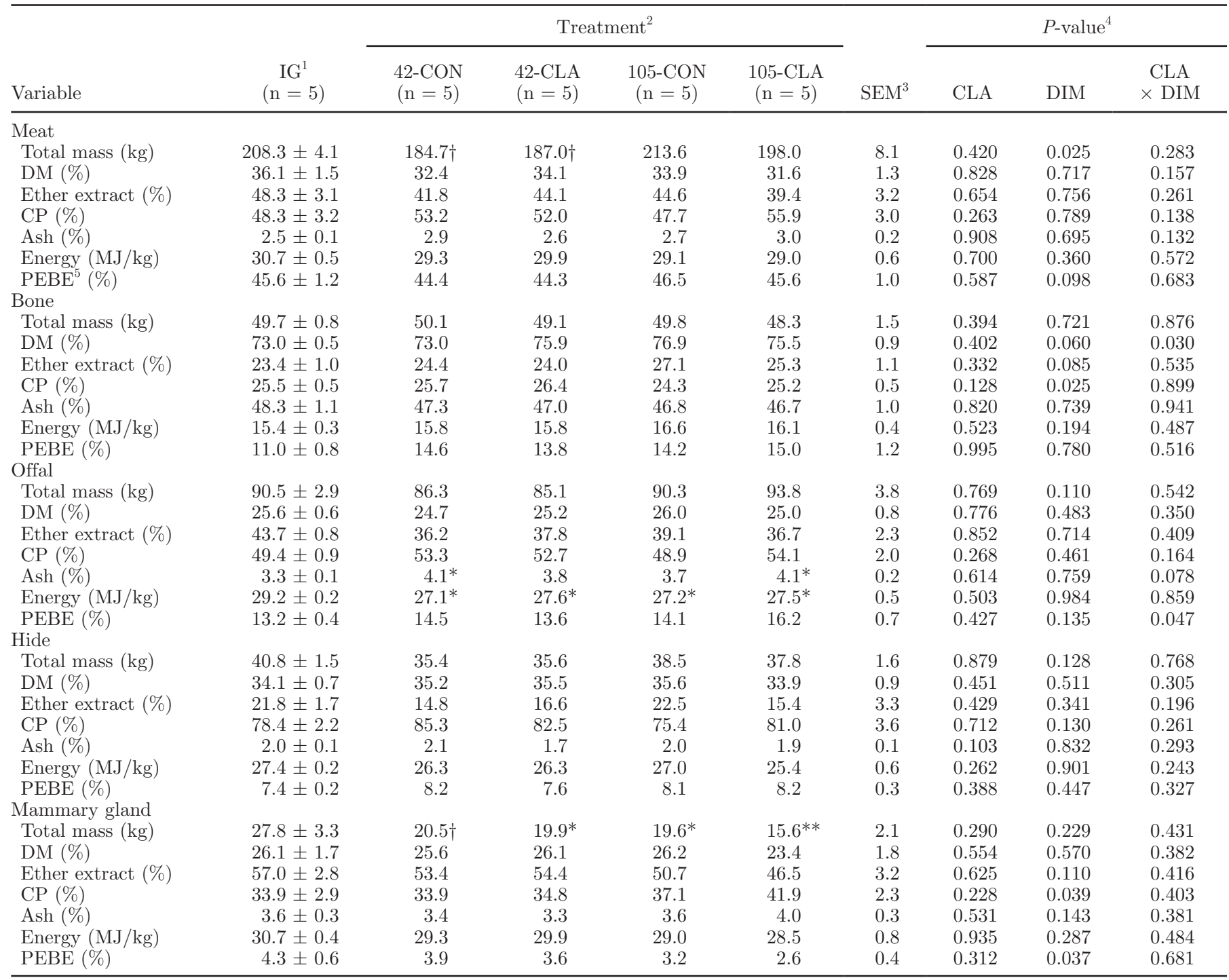

${ }^{1}$ Mean \pm SE of cows slaughtered at 1 DIM. Cows of the IG received no fat supplement and no CLA.

${ }^{2}$ Treatment: cows of the CLA groups consumed $6 \mathrm{~g} / \mathrm{d}$ of trans-10,cis-12 CLA and $6 \mathrm{~g} / \mathrm{d}$ of cis-9,trans-11 CLA. Cows of the CON groups received a control fat supplement in which the CLA were substituted by stearic acid.

${ }^{3}$ Pooled SEM included data from the CON and CLA groups slaughtered at 42 and 105 DIM without the IG.

${ }^{4}$ Statistical analyses with the GLM procedure included data from the CON and CLA groups slaughtered at 42 and 105 DIM without the IG. $P$-values in the CLA and DIM columns are related to the fixed effects of CLA supplementation and slaughter time at different DIM, respectively. $P$-values in the CLA $\times$ DIM column describe the interactions between the fixed effects.

${ }^{5}$ Proportion of empty body energy (PEBE) meant the percentage of empty body energy that was contained in the fraction.

$\dagger$ Indicates that means tended to be significantly different $(0.05<P<0.10)$ from those of the IG (Dunnett test); ${ }^{*}$ and ${ }^{* *}$ indicate that means are significantly different from those of the IG (Dunnett test; $P<0.05$ and $P<0.01$, respectively).

not $100 \%$, because of the proportion of carbohydrates in the different fractions.

The compositions of the retroperitoneal, mesenteric, omental, and s.c. fat fractions are shown in Table 4. Overall no CLA and DIM effects, or interactions between both, were found on the composition of the adipose depot fractions. The most pronounced effects were observed for the retroperitoneal fat depot fraction. The mass was decreased for the 42-CON, 105-CON, and 105-CLA groups compared with the IG, whereby the mass of the 42-CLA group tended to be decreased. This also resulted in a lower proportion of empty body 
Table 4. Total mass, DM, chemical composition of DM, and energy content in the 4 adipose depot fractions of cows slaughtered at different time points and fed no fat supplement (initial group, IG), the control (CON) diet, or conjugated linoleic acid (CLA)-supplemented diet

\begin{tabular}{|c|c|c|c|c|c|c|c|c|c|}
\hline Variable & $\begin{array}{c}\mathrm{IG}^{1} \\
(\mathrm{n}=5)\end{array}$ & \multicolumn{4}{|c|}{ Treatment $^{2}$} & $\mathrm{SEM}^{3}$ & \multicolumn{3}{|c|}{$P$-value ${ }^{4}$} \\
\hline \multicolumn{10}{|l|}{ Retroperitoneal fat } \\
\hline Total mass $(\mathrm{kg})$ & $8.8 \pm 1.0$ & $4.6^{*}$ & $5.8 \dagger$ & $5.6^{*}$ & $4.3^{* *}$ & 1.0 & 0.961 & 0.789 & 0.218 \\
\hline $\mathrm{DM}(\%)$ & $89.6 \pm 1.1$ & $83.7 \dagger$ & 86.3 & 84.5 & $79.0^{* *}$ & 2.1 & 0.499 & 0.136 & 0.069 \\
\hline Ether extract $(\%)$ & $97.1 \pm 0.5$ & 96.6 & 96.4 & 96.5 & 92.7 & 1.6 & 0.243 & 0.259 & 0.297 \\
\hline Energy (MJ/kg) & $39.0 \pm 0.2$ & 39.0 & 39.0 & 38.9 & 37.6 & 0.5 & 0.240 & 0.212 & 0.256 \\
\hline $\operatorname{PEBE}^{5}(\%)$ & $5.9 \pm 0.4$ & $3.7^{* *}$ & $4.3 \dagger$ & $3.9^{*}$ & $3.1^{* *}$ & 0.5 & 0.882 & 0.289 & 0.177 \\
\hline \multicolumn{10}{|l|}{ Omental fat } \\
\hline Total mass (kg) & $11.0 \pm 1.2$ & 7.6 & 9.1 & 8.5 & 7.4 & 1.1 & 0.860 & 0.743 & 0.258 \\
\hline $\mathrm{DM}(\%)$ & $81.4 \pm 0.7$ & 73.6 & 76.5 & 76.4 & 70.9 & 3.1 & 0.689 & 0.663 & 0.201 \\
\hline Ether extract (\%) & $95.8 \pm 0.7$ & 94.3 & 96.1 & 94.9 & 93.6 & 0.9 & 0.800 & 0.284 & 0.010 \\
\hline $\mathrm{CP}(\%)$ & $2.1 \pm 0.1$ & 4.0 & 3.0 & 3.3 & 4.0 & 0.6 & 0.734 & 0.812 & 0.177 \\
\hline \multicolumn{10}{|l|}{ Mesenteric fat } \\
\hline $\mathrm{DM}(\%)$ & $77.1 \pm 1.6$ & $67.4^{*}$ & 72.7 & $67.8^{*}$ & $64.8^{* *}$ & 2.6 & 0.679 & 0.177 & 0.135 \\
\hline Ether extract $(\%)$ & $95.6 \pm 0.9$ & 93.1 & 94.0 & 93.2 & 92.0 & 1.2 & 0.884 & 0.398 & 0.377 \\
\hline $\mathrm{CP}(\%)$ & $3.3 \pm 0.5$ & 4.9 & 3.9 & 5.0 & $5.6 \dagger$ & 0.6 & 0.694 & 0.122 & 0.191 \\
\hline $\operatorname{Ash}(\%)$ & $0.3 \pm 0.0$ & 0.5 & 0.3 & 0.4 & 0.4 & 0.1 & 0.340 & 0.798 & 0.127 \\
\hline Energy (MJ/kg) & $38.7 \pm 0.3$ & 38.1 & 38.3 & 38.2 & 37.8 & 0.4 & 0.750 & 0.641 & 0.544 \\
\hline PEBE (\%) & $3.5 \pm 0.2$ & 3.2 & 3.7 & $2.5^{*}$ & $2.7 \dagger$ & 0.3 & 0.206 & 0.009 & 0.649 \\
\hline \multicolumn{10}{|l|}{ s.c. fat } \\
\hline Total mass (kg) & $4.3 \pm 0.4$ & 3.3 & 4.9 & 3.8 & 3.0 & 0.7 & 0.580 & 0.334 & 0.117 \\
\hline $\mathrm{DM}(\%)$ & $75.7 \pm 2.1$ & 69.2 & 73.3 & 73.3 & 68.5 & 3.3 & 0.929 & 0.909 & 0.196 \\
\hline Ether extract (\%) & $90.6 \pm 1.3$ & 87.2 & 86.3 & 86.0 & 85.1 & 2.4 & 0.729 & 0.630 & 0.998 \\
\hline $\mathrm{CP}(\%)$ & $8.7 \pm 1.3$ & 9.2 & 9.5 & 9.3 & 9.4 & 1.7 & 0.927 & 0.990 & 0.957 \\
\hline $\operatorname{Ash}(\%)$ & $0.4 \pm 0.0$ & 0.5 & 0.4 & 0.2 & 0.5 & 0.1 & 0.424 & 0.298 & 0.090 \\
\hline Energy (MJ/kg) & $38.0 \pm 0.3$ & 36.8 & 36.5 & 36.4 & 36.0 & 0.9 & 0.733 & 0.590 & 0.983 \\
\hline PEBE $(\%)$ & $2.4 \pm 0.1$ & 2.1 & 2.9 & 2.2 & 1.8 & 0.4 & 0.614 & 0.202 & 0.168 \\
\hline
\end{tabular}

${ }^{1}$ Mean \pm SE of cows slaughtered at 1 DIM. Cows of the IG received no fat supplement and no CLA.

${ }^{2}$ Treatment: cows of the CLA groups consumed $6 \mathrm{~g} / \mathrm{d}$ of trans-10, cis-12 CLA and $6 \mathrm{~g} / \mathrm{d}$ of cis-9,trans-11 CLA. Cows of the CON groups received a control fat supplement in which the CLA were substituted by stearic acid.

${ }^{3}$ Pooled SEM included data from the CON and CLA groups slaughtered at 42 and 105 DIM without the IG.

${ }^{4}$ Statistical analyses with the GLM procedure included data from the CON and CLA groups slaughtered at 42 and 105 DIM without the IG. $P$-values in the CLA and DIM columns are related to the fixed effects of CLA supplementation and slaughter time at different DIM, respectively. $P$-values in the CLA $\times$ DIM column describe the interactions between the fixed effects.

${ }^{5}$ Proportion of empty body energy (PEBE) meant the percentage of empty body energy that was contained in the fraction.

$\dagger$ Indicates that means tended to be significantly different $(0.05<P<0.10)$ from those of the IG (Dunnett test); * and ** indicate that means are significantly different from those of the IG (Dunnett test; $P<0.05$ and $P<0.01$, respectively).

energy in the same groups. The DM content was lower in the 105-CLA group and tended to be lower in the 42 -CON group compared with the IG. Although the omental fat fraction remained unchanged, the mesenteric fat fraction was affected for DM, CP, and proportion of empty body energy (PEBE). The content of DM was lower in the 42-CON, 105-CON, and 105-CLA group compared with the IG. For PEBE, the groups slaughtered at 105 DIM were lower or tended to be lower. The effect on $\mathrm{CP}$ was only visible by a trend for a higher CP content in the 105-CLA group compared with the IG. The s.c. fat fraction did not differ in any of the determined variables.

\section{Correlation of BCS and BFT with Total Mass and Fat Mass of the Empty Body and the Fractions}

Table 5 shows the correlations of BCS and BFT with total mass or fat mass of the empty body and the 9 fractions for all animals regardless of group affiliation and grouped by slaughter at DIM. Including all animals, BCS and BFT was significantly correlated with total mass and fat mass of the empty body, meat, mammary gland, retroperitoneal fat, omental fat, and s.c. fat. Across early lactation, the correlations at 1, 42, and 105 DIM were not consistent. At 1 DIM, only significant correlations for the retroperitoneal and 
Table 5. Pearson correlation coefficients between BCS or back fat thickness (BFT) and total or fat mass for empty body composition or the different fractions [presented for all animals and for animals slaughtered at 1, 42, and 105 DIM; merged data of the control (CON) and conjugated linoleic acid (CLA) groups]

\begin{tabular}{|c|c|c|c|c|c|c|c|c|}
\hline Item & \multicolumn{2}{|c|}{ All $(\mathrm{n}=25)$} & \multicolumn{2}{|c|}{1 DIM $\left(\mathrm{IG}^{1} ; \mathrm{n}=5\right)$} & \multicolumn{2}{|c|}{$42 \operatorname{DIM}(\mathrm{n}=10)$} & \multicolumn{2}{|c|}{105 DIM $(\mathrm{n}=10)$} \\
\hline \multicolumn{9}{|l|}{ Empty body mass } \\
\hline Ether extract $(\mathrm{kg})$ & $0.616^{* *}$ & $0.582^{* *}$ & 0.911 & 0.330 & 0.101 & 0.018 & $0.798^{* *}$ & $0.814^{* *}$ \\
\hline \multicolumn{9}{|l|}{ Meat } \\
\hline Total mass $(\mathrm{kg})$ & $0.460^{*}$ & $0.500^{*}$ & 0.654 & -0.622 & -0.025 & 0.079 & $0.718^{*}$ & $0.796^{* *}$ \\
\hline Total mass $(\mathrm{kg})$ & -0.067 & 0.103 & -0.902 & -0.433 & -0.422 & -0.173 & 0.408 & 0.509 \\
\hline Ether extract $(\mathrm{kg})$ & -0.253 & -0.347 & -0.630 & -0.602 & $-0.551 \dagger$ & $-0.580 \dagger$ & 0.197 & 0.124 \\
\hline \multicolumn{9}{|l|}{ Offal } \\
\hline Total mass $(\mathrm{kg})$ & -0.137 & -0.127 & 0.691 & -0.532 & $-0.571 \dagger$ & -0.475 & 0.041 & 0.058 \\
\hline Ether extract $(\mathrm{kg})$ & 0.335 & 0.338 & 0.930 & -0.111 & -0.379 & -0.304 & $0.691 *$ & $0.699^{*}$ \\
\hline \multicolumn{9}{|l|}{ Hide } \\
\hline Total mass $(\mathrm{kg})$ & 0.205 & 0.214 & 0.728 & -0.611 & -0.137 & -0.310 & 0.220 & 0.292 \\
\hline Total mass $(\mathrm{kg})$ & $0.640 * * *$ & $0.665^{* * *}$ & $0.902^{*}$ & 0.414 & 0.242 & 0.167 & $0.854^{* *}$ & $0.841^{* *}$ \\
\hline Ether extract $(\mathrm{kg})$ & $0.642^{* * *}$ & $0.660^{* * *}$ & $0.917^{*}$ & 0.387 & 0.236 & 0.142 & $0.866^{* *}$ & $0.863^{* *}$ \\
\hline \multicolumn{9}{|l|}{ Omental fat } \\
\hline Total mass (kg) & $0.641 * * *$ & $0.540^{* *}$ & $0.973^{* *}$ & -0.053 & 0.232 & -0.016 & $0.791^{* *}$ & $0.840^{* *}$ \\
\hline Ether extract $(\mathrm{kg})$ & $0.668^{* * *}$ & $0.605^{* *}$ & $0.990^{* *}$ & 0.012 & 0.311 & 0.157 & $0.810^{* *}$ & $0.845^{* *}$ \\
\hline \multicolumn{9}{|l|}{ Mesenteric fat } \\
\hline Total mass $(\mathrm{kg})$ & 0.333 & 0.354 & 0.762 & 0.603 & -0.047 & -0.038 & $0.572 \dagger$ & $0.621 \dagger$ \\
\hline Ether extract $(\mathrm{kg})$ & $0.436^{*}$ & $0.490^{*}$ & 0.718 & 0.552 & 0.076 & 0.096 & $0.676^{*}$ & $0.742^{*}$ \\
\hline \multicolumn{9}{|l|}{ s.c. fat } \\
\hline Total mass (kg) & $0.546^{* *}$ & $0.445^{*}$ & 0.664 & 0.029 & 0.464 & 0.335 & $0.614 \dagger$ & $0.653^{*}$ \\
\hline Ether extract $(\mathrm{kg})$ & $0.600 * *$ & $0.494^{*}$ & 0.837 & 0.169 & 0.478 & 0.350 & $0.666^{*}$ & $0.698^{*}$ \\
\hline
\end{tabular}

${ }^{1} \mathrm{IG}=$ initial group.

$\dagger P<0.1 ;{ }^{*} P<0.05 ;{ }^{* *} P<0.01 ; * * * P<0.001$.

omental total mass and fat mass with BCS were detectable. At 42 DIM, no significant correlations were found. However, at 105 DIM, correlations of BCS and BFT with total mass and fat mass of the empty body, meat, retroperitoneal fat, omental fat, and s.c. fat were significant.

\section{Energy Metabolism, Mobilization, and Accretion of Body Fat and Protein}

In Table 6, the change of BW, change of EBM, AUC of BW data, the mobilized body fat, accreted body protein, and energy variables from 1 to 42 DIM are shown. No significant effect of CLA on body fat mobilization and protein accretion was observed. A trend for a decreased mobilization of body mass (fat and protein) was detected. The mobilized energy from body mass, $\mathrm{HP}$, energy efficiency, $\mathrm{MEI}$, and $\mathrm{NE}_{\mathrm{L}}$ remained unchanged in CLA-fed cows.

From 1 to 105 DIM (Table 7), fat mobilization was not different between the CON and CLA groups, whereas for protein, a higher accretion in the CLA group was observed. Transformed to energy equivalent, the retained energy in protein was also higher for CLA cows. The energy efficiency did not differ in this period. However, a trend for a decreased MEI and lower HP was detectable in CLA-supplemented cows.

From 42 up to 105 DIM (Table 8), no differences in mobilization of body reserves or influences of CLA on variables of the energy metabolism were observed. For the changes in BW, AUC for BW data, and changes of EBM, no differences between the CLA and CON group were observed in any of the periods. Furthermore the IGF-I blood plasma concentration increased with progress in lactation but was not influenced by CLA treatment during the first 105 DIM (Figure 1).

The mobilization of fat and energy from fat of the meat fraction was not influenced by CLA supplementation during the first 42 DIM. In the period from 42 to 105 DIM, a trend to higher fat, body mass, and energy mobilization from fat and body mass was observed in the CLA group (Table 9). 
Table 6. Change in BW and empty body mass (EBM), and mobilization (negative values) and accretion (positive values) of body fat and protein with assessment for energy metabolism from 1 to 42 DIM of cows fed the control $(\mathrm{CON})$ diet or conjugated linoleic acid (CLA)-supplemented diet (means $\pm \mathrm{SE}$ )

\begin{tabular}{|c|c|c|c|c|}
\hline \multirow[b]{2}{*}{ Item } & \multicolumn{2}{|c|}{ Treatment $^{1}$} & \multirow[b]{2}{*}{ Diff $^{2}$} & \multirow[b]{2}{*}{$P$-value } \\
\hline & $\begin{array}{c}42-\mathrm{CON} \\
(\mathrm{n}=5)\end{array}$ & $\begin{array}{l}\text { 42-CLA } \\
(\mathrm{n}=5)\end{array}$ & & \\
\hline BW change $(\mathrm{kg})$ & $-29.1 \pm 16.5$ & $-22.9 \pm 9.4$ & 6.2 & 0.754 \\
\hline $\mathrm{BW} \mathrm{AUC}^{3}(\mathrm{~kg} \times \mathrm{wk})$ & $2,957 \pm 93$ & $2,980 \pm 118$ & 23 & 0.885 \\
\hline EBM change $(\mathrm{kg})$ & $-44.5 \pm 13.2$ & $-37.3 \pm 8.8$ & 7.3 & 0.659 \\
\hline Fat $(\mathrm{kg})$ & $-24.1 \pm 4.0$ & $-14.3 \pm 5.2$ & 9.8 & 0.173 \\
\hline Protein (kg) & $2.8 \pm 1.0$ & $3.6 \pm 1.5$ & 0.8 & 0.680 \\
\hline Fat and protein $(\mathrm{kg})$ & $-21.3 \pm 3.5 \dagger$ & $-10.7 \pm 3.8 \dagger$ & 10.5 & 0.073 \\
\hline \multicolumn{5}{|l|}{ Energy $^{4}$} \\
\hline Fat (MJ/d) & $-22.8 \pm 3.8$ & $-13.5 \pm 4.9$ & 9.3 & 0.173 \\
\hline Protein (MJ/d) & $1.6 \pm 0.5$ & $2.0 \pm 0.9$ & 0.4 & 0.680 \\
\hline $\mathrm{E}_{\mathrm{G}}^{5}(\mathrm{MJ} / \mathrm{d})$ & $-21.2 \pm 3.5$ & $-11.5 \pm 4.1$ & 9.7 & 0.108 \\
\hline \multicolumn{5}{|l|}{ Energy metabolism } \\
\hline ME intake (MJ/d) & $180.9 \pm 11.2$ & $175.0 \pm 7.2$ & -5.9 & 0.670 \\
\hline $\mathrm{E}_{\mathrm{L}}(\mathrm{MJ} / \mathrm{d})$ & $79.1 \pm 6.3$ & $69.6 \pm 5.5$ & -9.5 & 0.290 \\
\hline $\mathrm{HP}^{6}(\mathrm{MJ} / \mathrm{d})$ & $123.0 \pm 8.7$ & $116.9 \pm 6.3$ & -6.1 & 0.585 \\
\hline Energy efficiency $^{7}$ & $6.4 \pm 0.2$ & $6.7 \pm 0.5$ & 0.4 & 0.520 \\
\hline
\end{tabular}

${ }^{1}$ Cows of the CLA group consumed $6 \mathrm{~g} / \mathrm{d}$ of trans-10,cis-12 CLA and $6 \mathrm{~g} / \mathrm{d}$ of cis-9,trans-11 CLA. Cows of the CON group received a control fat supplement in which the CLA were substituted by stearic acid.

${ }^{2}$ Difference $($ Diff $)=$ CLA - CON.

${ }^{3}$ Area under the curve (AUC): lower values represented an intensified decrease in BW.

${ }^{4}$ Represents the daily energy mobilized (negative) or retained (positive values) from the body components.

${ }^{5} \mathrm{E}_{\mathrm{G}}$ is the energy mobilized from (negative) or retained in (positive) body mass (fat and protein).

${ }^{6}$ Heat production.

${ }^{7}$ Describes the conversion of $1 \mathrm{~kg}$ of DMI into $\mathrm{NE}_{\mathrm{L}}$.

$\dagger$ Indicates that the marked means tended to be significantly $(P<0.10)$ different from each other.

The body fat mobilization for 42 -CON cows from 1 to 42 DIM was not correlated with plasma NEFA concentration (Figure 2A). Conversely, for the 42-CLA cows, this correlation was negative (Figure 2B). In the same period, body fat mobilization tended to be negatively correlated with net energy balance in the 42-CON group (Figure 2C) and tended to be positively correlated with net energy balance in the 42-CLA group (Figure 2D). No significant correlations were observed for the same variables from 1 to 105 DIM and from 42 to 105 DIM.

\section{Energy Partitioning}

Calculations for the proportions of $\mathrm{HP}, \mathrm{E}_{\mathrm{L}}$, and $\mathrm{E}_{\mathrm{G}}$ of the MEI are presented in Table 10. Within the 3 periods, the CLA and CON groups did not differ in percentage of $\mathrm{HP}, \mathrm{E}_{\mathrm{L}}$, or $\mathrm{E}_{\mathrm{G}}$ of MEI. The proportion of HP of MEI averaged $67.5 \%$ over the 42-CLA and 42-CON groups from 1 to 42 DIM and was higher compared with the average HP proportion from 42 to 105 DIM, and from calving to 105 DIM, 60.9\% $(P=0.017)$ and $62.0 \%(P=0.027)$, respectively. The $\mathrm{E}_{\mathrm{G}}$ proportion of MEI from calving to 42 DIM (-9.3\%) was lower than in the period from 42 to 105 DIM and from calving to 105 DIM, 0.9\% $(P<0.001)$ and $-2.2 \%(P=0.002)$.
The proportion of $\mathrm{E}_{\mathrm{L}}$ of MEI was $41.7 \%$ from calving to 42 DIM, $38.2 \%$ from 42 to 105 DIM, and $40.2 \%$ from calving to 105 DIM, and showed no differences between the periods.

\section{DISCUSSION}

\section{CLA Effects on Fat Metabolism in Dairy Cows}

In the present study, the body fat content at 42 and 105 DIM in CLA-supplemented cows were not different compared with the respective CON group (Table 2). This suggested that CLA supplementation during the first 42 or 105 DIM did not affect the mechanisms in fat metabolism active in regulation of body fat content in early lactation dairy cows. The unchanged plasma NEFA concentration and energy balance of cows used in the present study (von Soosten et al., 2011) support this conclusion and it appears that body fat mobilization, viewed as a major cause for the body composition at 42 or 105 DIM, was not influenced by CLA supplementation in early lactation. In several studies, plasma NEFA concentration and energy balance were not changed (Bernal-Santos et al., 2003; Castañeda-Gutiérrez et al., 2007). The study of Sinclair et al. (2010) reported no changes in carcass composition in CLA-fed lactating 
Table 7. Change in BW and empty body mass (EBM), and mobilization (negative values) and accretion (positive values) of body fat and protein with assessment for energy metabolism from 1 to 105 DIM of cows fed the control (CON) diet or conjugated linoleic acid (CLA)-supplemented diet (means $\pm \mathrm{SE}$ )

\begin{tabular}{|c|c|c|c|c|}
\hline \multirow[b]{2}{*}{ Item } & \multicolumn{2}{|c|}{ Treatment $^{1}$} & \multirow[b]{2}{*}{$\operatorname{Diff}^{2}$} & \multirow[b]{2}{*}{$P$-value } \\
\hline & $\begin{array}{c}105-\mathrm{CON} \\
(\mathrm{n}=5)\end{array}$ & $\begin{array}{c}\text { 105-CLA } \\
(\mathrm{n}=5)\end{array}$ & & \\
\hline BW change (kg) & $22.9 \pm 14.5$ & $6.8 \pm 19.8$ & -16.1 & 0.531 \\
\hline $\mathrm{BW}^{\mathrm{AUCC}}{ }^{3}(\mathrm{~kg} \times \mathrm{wk})$ & $7,762 \pm 232$ & $7,329 \pm 297$ & -433 & 0.283 \\
\hline EBM change (kg) & $-5.7 \pm 12.8$ & $-13.6 \pm 13.3$ & -7.9 & 0.684 \\
\hline Fat $(\mathrm{kg})$ & $-9.3 \pm 9.3$ & $-21.2 \pm 6.4$ & -11.9 & 0.321 \\
\hline Protein (kg) & $-1.0 \pm 1.0^{\mathrm{b}}$ & $3.3 \pm 1.3^{\mathrm{a}}$ & 4.3 & 0.027 \\
\hline Fat and protein $(\mathrm{kg})$ & $-10.3 \pm 8.6$ & $-17.8 \pm 5.3$ & -7.6 & 0.474 \\
\hline \multicolumn{5}{|l|}{ Energy $^{4}$} \\
\hline Fat $(\mathrm{MJ} / \mathrm{d})$ & $-2.7 \pm 2.7$ & $-6.2 \pm 1.9$ & -3.5 & 0.321 \\
\hline Protein $(\mathrm{MJ} / \mathrm{d})$ & $-0.2 \pm 0.4^{\mathrm{b}}$ & $0.8 \pm 0.3^{\mathrm{a}}$ & 1.0 & 0.027 \\
\hline $\mathrm{E}_{\mathrm{G}}{ }^{5}(\mathrm{MJ} / \mathrm{d})$ & $-2.9 \pm 2.6$ & $-5.4 \pm 1.6$ & -2.5 & 0.433 \\
\hline \multicolumn{5}{|l|}{ Energy metabolism } \\
\hline $\mathrm{ME}$ intake (MJ/d) & $202.2 \pm 3.7 \dagger$ & $187.2 \pm 5.6 \dagger$ & -15.0 & 0.057 \\
\hline $\mathrm{E}_{\mathrm{J}}(\mathrm{MJ} / \mathrm{d})$ & $79.2 \pm 2.7$ & $77.1 \pm 2.5$ & -2.1 & 0.589 \\
\hline $\mathrm{HP}^{6}(\mathrm{MJ} / \mathrm{d})$ & $125.9 \pm 1.3^{\mathrm{a}}$ & $115.5 \pm 3.7^{\mathrm{b}}$ & -10.4 & 0.029 \\
\hline Energy efficency $^{7}$ & $6.6 \pm 0.1$ & $6.8 \pm 0.1$ & 0.2 & 0.244 \\
\hline
\end{tabular}

$\overline{\mathrm{a}, \mathrm{b}}$ Different letters within a row denote significance differences $(P<0.05)$.

${ }^{1}$ Cows of the CLA group consumed $6 \mathrm{~g} / \mathrm{d}$ of trans-10, cis-12 CLA and $6 \mathrm{~g} / \mathrm{d}$ of cis-9,trans-11 CLA. Cows of the CON group received a control fat supplement in which the CLA were substituted by stearic acid.

${ }^{2}$ Difference $($ Diff $)=$ CLA - CON.

${ }^{3}$ Area under the curve (AUC): lower values represented an intensified decrease in BW.

${ }^{4}$ Represents the daily energy mobilized (negative) or retained (positive values) from the body components.

${ }^{5} \mathrm{E}_{\mathrm{G}}$ is the energy mobilized from (negative) or retained in (positive) body mass (fat and protein).

${ }^{6}$ Heat production.

${ }^{7}$ Describes the conversion of $1 \mathrm{~kg}$ of DMI into $\mathrm{NE}_{\mathrm{L}}$.

$\dagger$ Indicates that the marked means tended to be significantly $(P<0.10)$ different from each other.

ewes. None of these studies evaluated body fat mobilization. In growing mice, fed higher laboratory dosages of CLA, a marked reduction in body fat content was shown (Park et al., 1997; DeLany et al., 1999; Wang and Jones, 2004). However, the effects of CLA on fat metabolism are not well investigated in ruminants and the transmissibility from mice to ruminants is not possible because of differences in fat metabolism between mice and ruminants described by Pearce (1983). Body condition score and BFT are commonly used as indicators for body composition to estimate the mobilization of body reserves in lactating dairy cows. No correlations of BCS and BFT with total mass and fat mass of the empty body and the different fractions were observed at 42 DIM in the present study (Table 5). This suggested that the assessment of development of body composition and the different fat depots in early lactation by $\mathrm{BCS}$ or BFT, which mainly reflect the changes in the s.c. fat depot, do not adequately illustrate the different changes in adipose depots and body fat mobilization during early lactation.

The present study was designed to calculate values for body fat mobilization. An initial body composition at 1 DIM could be calculated for each animal slaughtered after 42 or 105 DIM, including body composi- tion data of the IG and applying the principle of the comparative slaughter technique according to Bath et al. (1965). This initial body composition offers the opportunity to determine body fat mobilization. By using the comparative slaughter technique, it is important to be aware that for calculation of fat or protein mobilization and accretion, the animals were slaughtered at different stages. The suggestion of the average body composition of the IG for the animals slaughtered at 42 or 105 DIM to calculate a start body composition at 1 DIM, of the animals actually slaughtered later, assumed that the animals slaughtered at 42 and 105 DIM underwent similar changes in body composition to the animals of the IG. This aspect of the method also has to be considered in the calculation of the body composition at 42 DIM of the animals slaughtered after 105 DIM. Therefore, we only used primiparous cows with a small variation in age and BW at 1 DIM to create optimal prerequisites for similar changes in body composition during the trial, irrespective of treatment.

Compared with the $42-\mathrm{CON}$ group, the mobilized body fat mass was numerically decreased $(40.7 \%)$ in the 42-CLA group from 1 to 42 DIM (Table 6) and accounted with $93.3 \%$ for the trend of reduced body mass mobilization in the CLA group. Conversely, little 


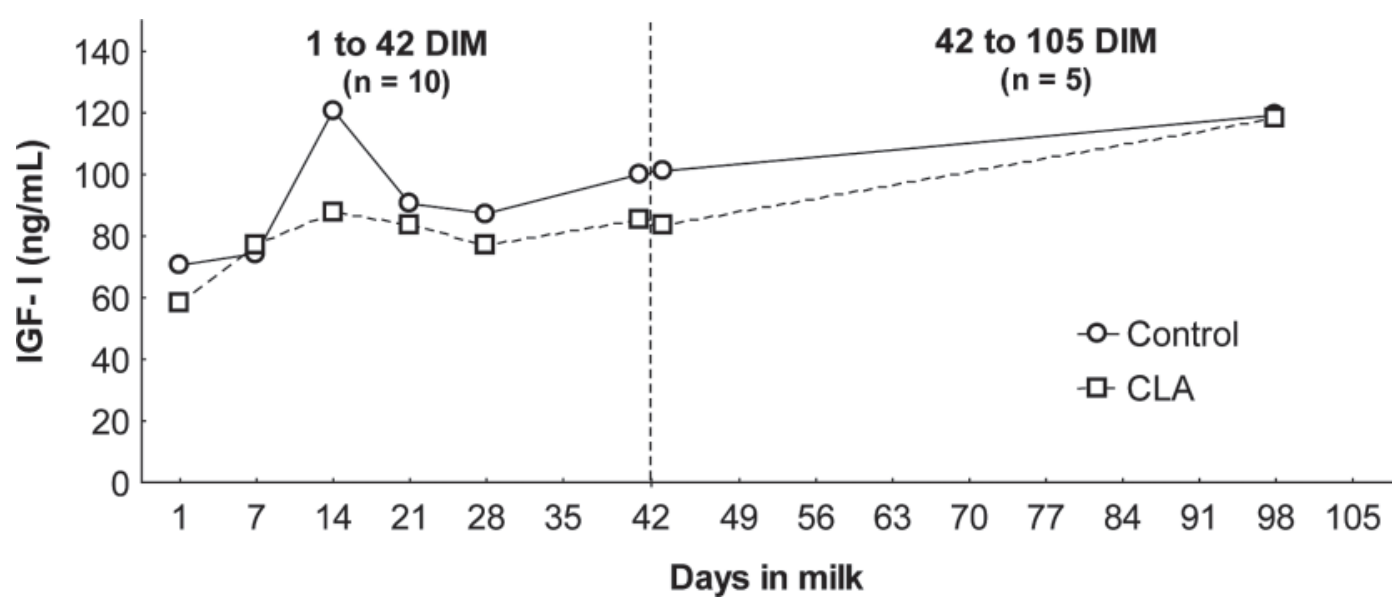

Figure 1. Development of IGF-I plasma concentrations (means) during the trial. From 1 to 42 DIM, each group consisted of 10 animals and from 42 to 105 DIM, samples of 5 animals in each group were available, because of the slaughter after 42 DIM. Cows received from 1 DIM to slaughter a control fat supplement (CON) or a conjugated linoleic acid (CLA) supplement. Animals of the CLA group consumed 6 g/d each of trans-10,cis-12 CLA and cis-9,trans-11 CLA. No differences between the groups were observed from 1 to 42 DIM $(P=0.219)$ and the standard error of the means averaged 6.9 and ranged from 5.4 to $10.0 \mathrm{ng} / \mathrm{mL}$. From 42 to 105 DIM, no differences between the groups were observed ( $P$ $=0.566)$ and the standard error of the means averaged 9.5 and ranged from 9.6 to $9.4 \mathrm{ng} / \mathrm{mL}$. With progress of DIM, the IGF-I values increased from 1 to 42 DIM $(P<0.001)$ and a trend for an increase was noted from 42 to 105 DIM $(P=0.070)$.

evidence was found that plasma NEFA concentrations of cows used in the present study (von Soosten et al., 2011) corroborated the trend for lower body mass mobilization. The correlation of body fat mobilization with plasma NEFA concentration during the first 42 DIM for the 42-CON cows showed a relationship of higher body fat mobilization associated with higher plasma NEFA concentration (Figure 2A). Furthermore, this relationship and the relationship between body fat mobilization and negative energy balance are reported by

Table 8. Change in BW and empty body mass (EBM), and mobilization (negative values) and accretion (positive values) of body fat and protein with assessment for energy metabolism from 42 to 105 DIM of cows fed the control $(\mathrm{CON})$ diet or conjugated linoleic acid (CLA)-supplemented diet (means $\pm \mathrm{SE}$ )

\begin{tabular}{|c|c|c|c|c|}
\hline \multirow[b]{2}{*}{ Item } & \multicolumn{2}{|c|}{ Treatment $^{1}$} & \multirow[b]{2}{*}{ Diff $^{2}$} & \multirow[b]{2}{*}{$P$-value } \\
\hline & $\begin{array}{c}105-\mathrm{CON} \\
(\mathrm{n}=5)\end{array}$ & $\begin{array}{c}\text { 105-CLA } \\
(\mathrm{n}=5)\end{array}$ & & \\
\hline BW change (kg) & $20.2 \pm 4.8$ & $21.4 \pm 12.6$ & 1.2 & 0.933 \\
\hline $\mathrm{BW} \mathrm{AUC}^{3}(\mathrm{~kg} \times \mathrm{wk})$ & $4,710 \pm 142$ & $4,410 \pm 198$ & -300 & 0.253 \\
\hline EBM change (kg) & $17.6 \pm 8.7$ & $16.3 \pm 4.4$ & -1.3 & 0.897 \\
\hline Fat $(\mathrm{kg})$ & $11.5 \pm 9.1$ & $-5.6 \pm 5.1$ & -17.2 & 0.138 \\
\hline Protein $(\mathrm{kg})$ & $-1.0 \pm 1.6$ & $2.7 \pm 1.4$ & 3.7 & 0.124 \\
\hline Fat and protein $(\mathrm{kg})$ & $10.6 \pm 8.5$ & $-2.9 \pm 3.9$ & -13.5 & 0.189 \\
\hline \multicolumn{5}{|l|}{ Energy $^{4}$} \\
\hline Fat $(\mathrm{MJ} / \mathrm{d})$ & $7.3 \pm 5.7$ & $-3.6 \pm 3.2$ & -10.8 & 0.138 \\
\hline Protein $(\mathrm{MJ} / \mathrm{d})$ & $-0.4 \pm 0.6$ & $1.0 \pm 0.5$ & 1.4 & 0.124 \\
\hline $\mathrm{E}_{\mathrm{G}}^{5}(\mathrm{MJ} / \mathrm{d})$ & $6.9 \pm 5.5$ & $-2.5 \pm 2.8$ & -9.4 & 0.164 \\
\hline \multicolumn{5}{|l|}{ Energy metabolism } \\
\hline ME intake (MJ/d) & $219.4 \pm 4.7$ & $202.1 \pm 10.2$ & -17.3 & 0.161 \\
\hline $\mathrm{E}_{\mathrm{J}}(\mathrm{MJ} / \mathrm{d})$ & $82.4 \pm 2.3$ & $78.3 \pm 3.7$ & -4.1 & 0.384 \\
\hline $\mathrm{HP}^{6}(\mathrm{MJ} / \mathrm{d})$ & $130.1 \pm 2.9$ & $126.3 \pm 6.9$ & -3.8 & 0.625 \\
\hline Energy efficency $^{7}$ & $6.8 \pm 0.2$ & $6.6 \pm 0.2$ & -0.2 & 0.521 \\
\hline
\end{tabular}

${ }^{1}$ Cows of the CLA group consumed $6 \mathrm{~g} / \mathrm{d}$ of trans-10,cis-12 CLA and $6 \mathrm{~g} / \mathrm{d}$ of cis-9,trans-11 CLA. Cows of the CON group received a control fat supplement in which the CLA were substituted by stearic acid.

${ }^{2}$ Difference $($ Diff $)=$ CLA - CON.

${ }^{3}$ Area under the curve (AUC): lower values represented an intensified decrease in BW.

${ }^{4}$ Represents the daily energy mobilized (negative) or retained (positive values) from the body components.

${ }^{5} \mathrm{E}_{\mathrm{G}}$ is the energy mobilized from (negative) or retained in (positive) body mass (fat and protein).

${ }^{6}$ Heat production.

${ }^{7}$ Describes the conversion of $1 \mathrm{~kg}$ of DMI into $\mathrm{NE}_{\mathrm{L}}$. 
Table 9. Mobilization (negative values) and accretion (positive values) of body fat and protein and its energy (means) in the meat fraction during 3 time periods in early lactation of cows fed the control (CON) diet or conjugated linoleic acid (CLA)-supplemented diet

\begin{tabular}{|c|c|c|c|c|c|c|c|c|c|c|c|c|}
\hline \multirow[b]{3}{*}{ Item } & \multicolumn{4}{|c|}{1 to 42 DIM } & \multicolumn{4}{|c|}{42 to 105 DIM } & \multicolumn{4}{|c|}{1 to 105 DIM } \\
\hline & \multicolumn{2}{|c|}{ Treatment $^{1}$} & \multirow[b]{2}{*}{$\mathrm{SEM}^{2}$} & \multirow[b]{2}{*}{$P$-value } & \multicolumn{2}{|c|}{ Treatment $^{1}$} & \multirow[b]{2}{*}{$\mathrm{SEM}^{2}$} & \multirow[b]{2}{*}{$P$-value } & \multicolumn{2}{|c|}{ Treatment $^{1}$} & \multirow[b]{2}{*}{$\mathrm{SEM}^{2}$} & \multirow[b]{2}{*}{$P$-value } \\
\hline & $42-\mathrm{CON}$ & 42-CLA & & & $105-\mathrm{CON}$ & 105-CLA & & & $105-\mathrm{CON}$ & 105-CLA & & \\
\hline Fat $(\mathrm{kg})$ & -11.4 & -7.6 & 2.0 & 0.215 & $8.4 \dagger$ & $-3.1 \dagger$ & 4.2 & 0.088 & -2.9 & -9.5 & 4.4 & 0.313 \\
\hline Protein $(\mathrm{kg})$ & -3.8 & -2.6 & 1.8 & 0.648 & 2.3 & 1.7 & 1.0 & 0.633 & -1.3 & 0.2 & 1.1 & 0.365 \\
\hline Fat and protein $(\mathrm{kg})$ & -15.2 & -10.1 & 2.2 & 0.143 & $10.7 \dagger$ & $-1.4 \dagger$ & 4.1 & 0.070 & -4.2 & -9.4 & 4.7 & 0.459 \\
\hline Fat $(\mathrm{MJ} / \mathrm{d})$ & -10.8 & -7.2 & 1.9 & 0.215 & $-3.8 \dagger$ & $-1.9 \dagger$ & 2.6 & 0.088 & -1.1 & -3.6 & 1.7 & 0.313 \\
\hline Protein (MJ/d) & -2.1 & -1.5 & 1.0 & 0.648 & 0.9 & 0.6 & 0.4 & 0.633 & -0.5 & 0.0 & 0.2 & 0.361 \\
\hline $\mathrm{E}_{\mathrm{G}}{ }^{3}(\mathrm{MJ} / \mathrm{d})$ & -13.0 & -8.6 & 1.8 & 0.133 & $6.2 \dagger$ & $-1.3 \dagger$ & 2.6 & 0.076 & -1.4 & -3.6 & 1.7 & 0.395 \\
\hline
\end{tabular}

${ }^{1}$ Cows of the CLA group consumed $6 \mathrm{~g} / \mathrm{d}$ of trans-10, cis-12 CLA and $6 \mathrm{~g} / \mathrm{d}$ of cis-9,trans-11 CLA. Cows of the CON group received a control fat supplement in which the CLA were substituted by stearic acid.

${ }^{2}$ Pooled SEM.

${ }^{3} \mathrm{E}_{\mathrm{G}}$ is the energy mobilized from (negative) or retained in (positive) body mass (fat and protein).

$\dagger$ Indicates that the marked means tended to be significantly $(P<0.10)$ different from each other.

Table 10. Partitioning of ME intake (MEI) into heat production (HP), milk energy, and body mass during 3 time periods with or without conjugated linoleic acid (CLA) supplementation in early lactation (percentage values of MEI)

\begin{tabular}{|c|c|c|c|c|c|c|c|c|c|c|c|c|}
\hline \multirow[b]{3}{*}{ Item } & \multicolumn{4}{|c|}{1 to $42 \mathrm{DIM}$} & \multicolumn{4}{|c|}{42 to 105 DIM } & \multicolumn{4}{|c|}{1 to 105 DIM } \\
\hline & \multicolumn{2}{|c|}{ Treatment $^{1}$} & \multirow[b]{2}{*}{$\mathrm{SEM}^{2}$} & \multirow[b]{2}{*}{$P$-value } & \multicolumn{2}{|c|}{ Treatment $^{1}$} & \multirow[b]{2}{*}{$\mathrm{SEM}^{2}$} & \multirow[b]{2}{*}{$P$-value } & \multicolumn{2}{|c|}{ Treatment $^{1}$} & \multirow[b]{2}{*}{$\mathrm{SEM}^{2}$} & \multirow[b]{2}{*}{$P$-value } \\
\hline & 42-CON & 42-CLA & & & $105-\mathrm{CON}$ & 105-CLA & & & $105-\mathrm{CON}$ & 105-CLA & & \\
\hline $\mathrm{HP}^{3}$ (\% of MEI) & 67.9 & 67.1 & 3.3 & 0.866 & 59.4 & 62.5 & 1.6 & 0.217 & 62.3 & 61.7 & 0.8 & 0.583 \\
\hline $\mathrm{E}_{\mathrm{L}_{5}}^{4}(\%$ of MEI $)$ & 44.0 & 39.6 & 2.8 & 0.308 & 37.5 & 38.8 & 0.9 & 0.338 & 39.2 & 41.3 & 1.2 & 0.239 \\
\hline $\mathrm{E}_{\mathrm{G}}{ }^{5}(\%$ of $\mathrm{MEI})$ & -11.9 & -6.7 & 2.3 & 0.155 & 3.0 & -1.3 & 2.0 & 0.157 & -1.5 & -3.0 & 1.1 & 0.379 \\
\hline \multicolumn{13}{|l|}{$\begin{array}{l}{ }^{1} \text { Cows of the CLA } \\
\text { were substituted } \mathrm{l} \\
{ }^{2} \text { Pooled SEM. } \\
{ }^{3} \mathrm{HP} / \mathrm{MEI} \times 100 . \\
{ }^{4} \mathrm{E}_{\mathrm{L}} / \mathrm{MEI} \times 100 . \\
{ }^{5} \mathrm{E}_{\mathrm{G}} / \mathrm{MEI} \times 100\end{array}$} \\
\hline
\end{tabular}


A

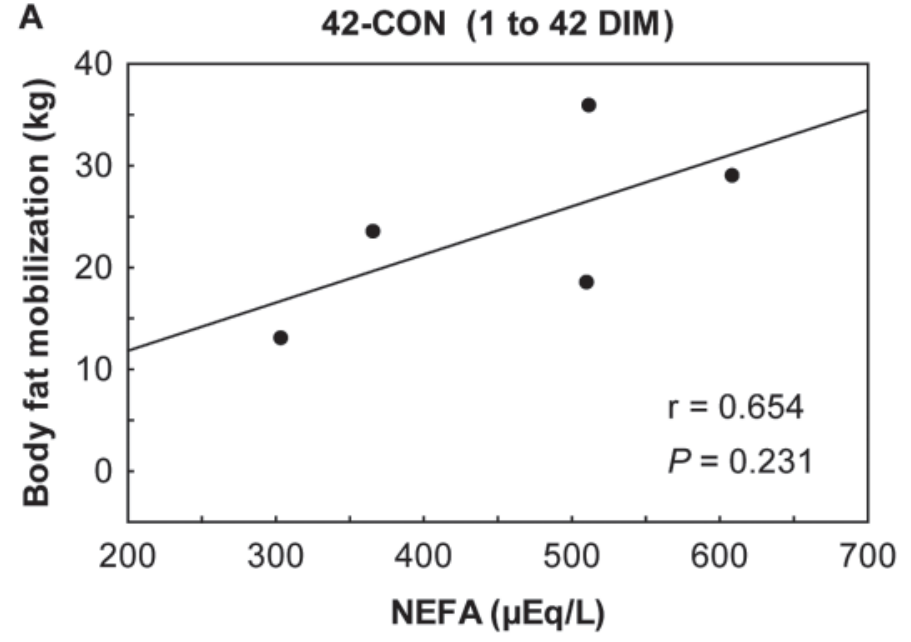

C

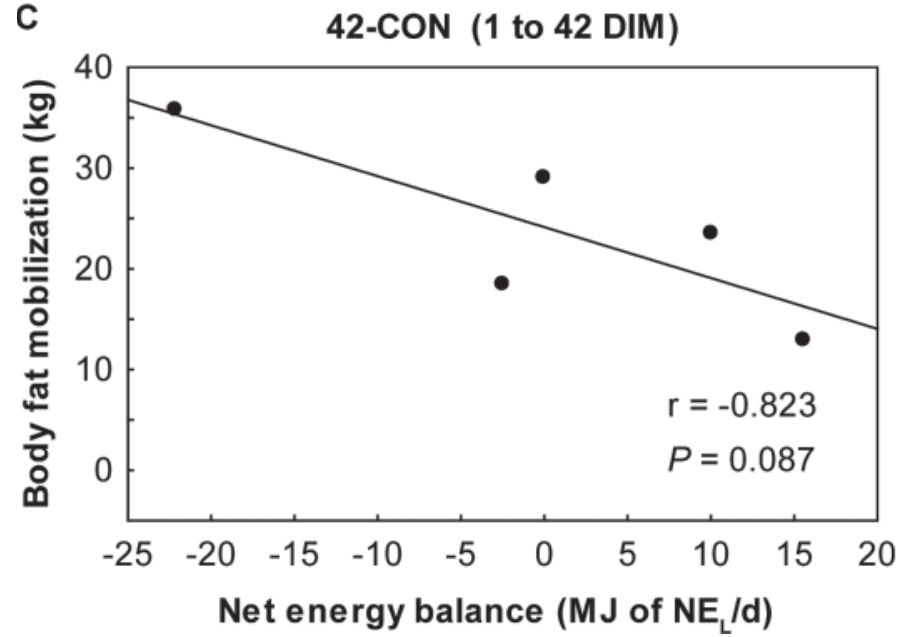

B

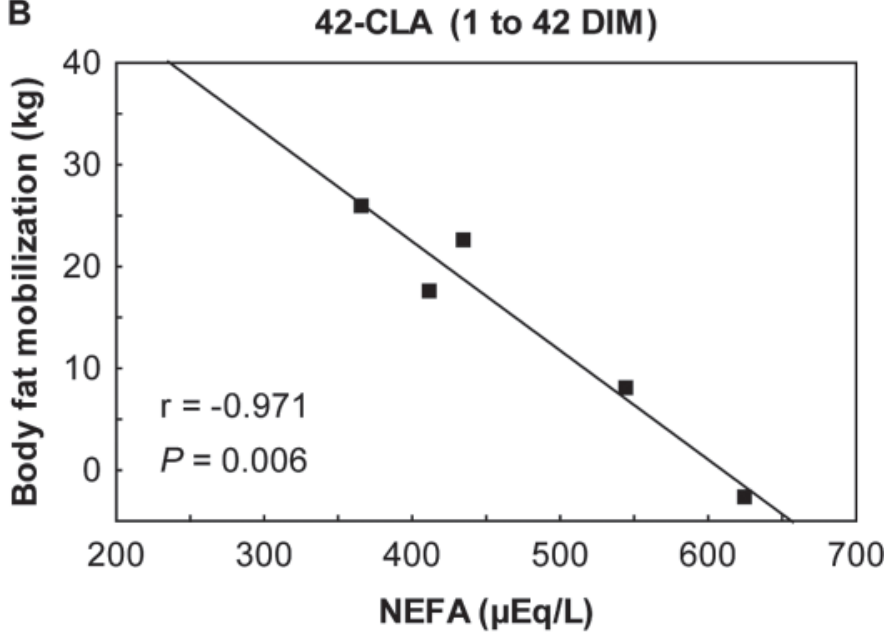

D 42 -CLA ( 1 to 42 DIM)

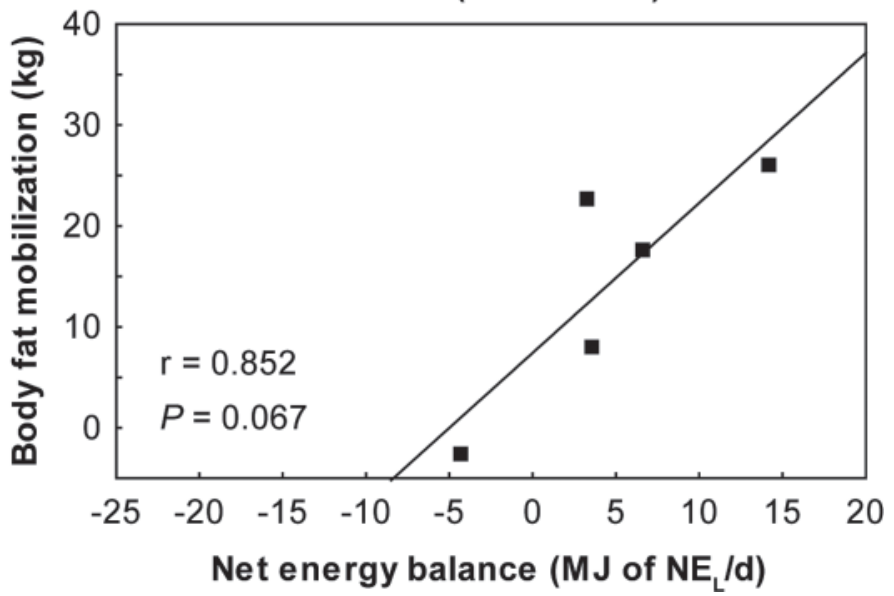

Figure 2. Relationship (Pearson correlation coefficient $\mathrm{r}$ ) between body fat mobilization and indicators of body fat mobilization (blood plasma NEFA concentration and calculated net energy balance) from 1 to 42 DIM of cows fed the control fat preparation $(42-\mathrm{CON}$, $\mathrm{n}=5)$ or the conjugated linoleic acid supplement $(42-\mathrm{CLA}, \mathrm{n}=5)$.

Vernon (1980). In contrast, the body fat mobilization of the 42-CLA cows from 1 to 42 DIM was negatively correlated with plasma NEFA concentration (Figure 2B) and a correlation between body fat mobilization and net energy balance was not apparent for the 42CLA group (Figure 2D), whereas in the $42-\mathrm{CON}$ group, this relationship was evident (Figure 2C). Explanations for these observations are rather difficult; conceivable could be CLA effects on lipolysis and lipogenesis in the different adipose tissues of the dairy cow, which could have caused the observed effects on body mass mobilization. In dairy cows used in the present study, the retroperitoneal adipose depot mass tended to be less reduced in CLA-fed animals (von Soosten et al., 2011). For the same animals used in the present study, Akter et al. (2011) measured adipocyte area, and animals of the CLA group showed a decreased adipocyte area in s.c. and mesenteric adipose tissue at 42 and 105 DIM, as well as in omental and retroperitoneal fat at 105 DIM. However, the correlations between adipocyte area and plasma NEFA concentrations for the CON cows and the IG were strongly positive for the retroperitoneal fat depot $(\mathrm{r}=0.698)$ and the visceral fat depots $(\mathrm{r}$ $=0.602$ ). The adipocyte area of the CLA cows was not correlated with plasma NEFA concentration. This does not deliver an explanation for the different correlations of body fat mobilization and plasma NEFA concentration, but it supports and is in accordance with the calculated correlations in the present study.

In a short-term abomasal infusion study of trans10, cis-12 CLA ( $7.5 \mathrm{~g} / \mathrm{d})$ with dairy cows, Harvatine et al. (2009) observed increased expression of lipid synthesis-related genes in s.c. adipose tissue. Furthermore, the expression of peroxisome proliferator-activated receptor 
gamma (PPAR $\gamma$ ), which is involved in lipid deposition in adipose tissue, was increased. For cows used in the present study, Saremi et al. (2011) showed an increased mRNA abundance of PPAR $\gamma$ in visceral adipose tissue for the CLA-treated animals.

Overall, no effects of CLA supplementation on body fat content and mobilization were observed and the trend for decreased body mass mobilization in CLAsupplemented cows is mainly explained through the numerically reduced body fat mobilization. This and the changed relationships of body fat mobilization with plasma NEFA concentrations and energy balance in CLA-fed cows suggested a CLA influence on fat metabolism in the early lactation dairy cow.

\section{CLA Effects on Protein Metabolism in Dairy Cows}

In the present investigation, CLA supplementation enhanced protein accretion from 1 to 105 DIM (Table 7). Protein turnover comprises protein synthesis and degradation. That means that the observed protein accretion is the net balance between protein synthesis and protein degradation (Stangl, 2010). Feeding of CLA to double-muscled Piemontese young bulls improved feed efficiency. Despite feeding a low-protein diet containing $108 \mathrm{~g}$ of $\mathrm{CP} / \mathrm{kg}$ of DM to the animals, the ADG was not decreased in the CLA group. This suggests that CLA affects protein turnover and compensated for the lack of dietary CP (Schiavon et al., 2010). The possible CLA effects on protein anabolism might be mediated by anabolic hormones like IGF-I. This growth factor is part of the somatotropic axis, which describes the interaction of growth hormone, growth hormone receptors in the liver, and IGF-I synthesized and secreted by the liver (Lucy et al., 2001). The study by CastañedaGutiérrez et al. (2007) showed increased plasma IGF-I concentrations during supplementation of $7.1 \mathrm{~g} / \mathrm{d}$ each of cis-9,trans-11 and trans-10,cis-12 CLA from 20 to 56 DIM. For cows of the present trial, IGF-I values were not influenced by CLA treatment (Figure 1). This might be because primiparous cows have not completed growth and, therefore, the IGF-I in blood plasma concentration is higher (Weber et al., 2007). Nevertheless, IGF-I could stimulate protein synthesis (Svanberg et al., 1996) and further research is needed to clarify an effect of CLA on protein metabolism in growing ruminants and in the periparturient period of dairy cows.

\section{CLA Effects on Energy Metabolism and Energy Partitioning in Dairy Cows}

Significant differences in energy partitioning between the CON and CLA group were not detectable (Table 10). The average daily energy mobilization during the first 42 DIM was numerically lower $(9.3 \mathrm{MJ} / \mathrm{d})$ in CLAfed cows. Additionally, considering the energy accreted in body protein, the energy mobilized from body mass was $9.7 \mathrm{MJ} / \mathrm{d}$ lower in this period compared with the CON group (Table 6). The PEBE showed that most of total body energy originated from the meat fraction (Table 3) and $4.4 \mathrm{MJ} / \mathrm{d}$ less energy was mobilized from the meat fraction in the CLA group in the first 42 DIM (Table 9). These effects are not associated with a decreased $\mathrm{E}_{\mathrm{L}}$ or higher MEI in CLA-fed cows. On the contrary, the $\mathrm{E}_{\mathrm{L}}$ was equal and DMI tended to be decreased by CLA treatment (Table 6 and 7 ). This is in line with other studies observing no influence on $\mathrm{E}_{\mathrm{L}}$ (Bernal-Santos et al., 2003; Sinclair et al., 2010) due to repartitioning of energy spared by decrease in milk fat content to a higher milk yield. Furthermore, a decreased DMI was shown by Moallem et al. (2010), Pappritz et al. (2011), and in a meta-analysis by Harvatine et al. (2009) for CLA-supplemented dairy cows.

The HP from 1 to 42 DIM was unchanged and from calving to 105 DIM was decreased in the CLA group of the present study (Table 6 and 7). In CLA-fed mice, a higher HP was observed and was explained by concurrent marked reductions of adipose depots or reduction in body fat content (West et al., 1998, 2000). The converse effects on HP in dairy cows of the present study could be related to higher CLA dosages fed to mice (Bauman et al., 2008) and differences between the fat metabolism in mice and ruminants (Vernon, 1980). However, the trend for a decreased HP in CLA-fed cows (Table 7) could be due to lower DMI, which led to lower production of metabolic heat. Higher DMI is associated with a higher heat increment of feeding (Wenk et al., 2001). Nevertheless, values for the HP measured in this trial are in the range of HP measured by van Knegsel et al. (2007) in dairy cows.

The effects of CLA on energy partitioning in the first 105 DIM are of minor importance. The numerically lower amount of energy needed from body reserves $\left(\mathrm{E}_{\mathrm{G}}\right)$ is a result of the trend for a lower body mass mobilization from 1 to 42 DIM and an improved conversion of the ME into the products could be suggested during the first 42 DIM.

\section{CONCLUSIONS}

The results of the present study indicated no effects of trans-10,cis-12 and cis-9,trans-11 CLA supplementation on body composition of dairy cows. The slightly decreased body mass mobilization from 1 to 42 DIM in the CLA group and the increased protein accretion, decreased HP, and a trend to lower DMI from 1 to 105 DIM for CLA-supplemented dairy cows in relation to the unchanged $\mathrm{E}_{\mathrm{L}}$, indicate a lower energy expense by 
equal $\mathrm{E}_{\mathrm{L}}$ and more energy retained in body protein. This suggested an improved utilization of the ME in CLA-fed early lactation dairy cows.

\section{ACKNOWLEDGMENTS}

The authors thank the Deutsche Forschungsgemeinschaft (DFG, Bonn, Germany) for financial support (PAK 286/1, DA 558/5-1). Furthermore, the assistance of the coworkers of the Institute of Animal Nutrition and the experimental station of the Friedrich-LoefflerInstitute (FLI) in Brunswick Germany, in performing the experiment and analyses, is gratefully acknowledged.

\section{REFERENCES}

Akter, S. H., S. Häussler, S. Dänicke, U. Müller, D. von Soosten, J Rehage, and H. Sauerwein. 2011. Physiological and conjugated linoleic acids-induced changes of adipocyte size in different fat depots of dairy cows during early lactation. J. Dairy Sci. 94:2871-2882.

Bath, D. L., M. Ronning, J. H. Meyer, and G. P. Lofgreen. 1965. Caloric equivalent of live weight loss of dairy cattle. J. Dairy Sci. 48:374-380.

Bauman, D. E., and W. B. Currie. 1980. Partitioning of nutrients during pregnancy and lactation-A review of mechanisms involving homeostasis and homeorhesis. J. Dairy Sci. 63:1514-1529.

Bauman, D. E., J. W. Perfield, K. J. Harvatine, and L. H. Baumgard. 2008. Regulation of fat synthesis by conjugated linoleic acid: Lactation and the ruminant model. J. Nutr. 138:403-409.

Baumgard, L. H., B. A. Corl, D. A. Dwyer, A. Saebø, and D. E. Bauman. 2000. Identification of the conjugated linoleic acid isomer that inhibits milk fat synthesis. Am. J. Physiol. Regul. Integr. Comp. Physiol. 278:R179-R184.

Bernal-Santos, G., J. W. Perfield, D. M. Barbano, D. E. Bauman, and T. R. Overton. 2003. Production responses of dairy cows to dietary supplementation with conjugated linoleic acid (CLA) during the transition period and early lactation. J. Dairy Sci. 86:3218-3228.

Brouwer, E. 1965. Report of sub-committee on constants and factors. Pages 441-443 in Proc. 3rd Symposium on Energy Metabolism. K. L. Baxter, ed. European Association for Animal Production, publ. No. 11. Academic Press, London, UK.

Castañeda-Gutiérrez, E., B. C. Benefield, M. J. de Veth, N. R. Santos, R. O. Gilbert, W. R. Butler, and D. E. Bauman. 2007. Evaluation of the mechanism of action of conjugated linoleic acid isomers on reproduction in dairy cows. J. Dairy Sci. 90:4253-4264.

de Veth, M. J., E. Castañeda-Gutiérrez, D. A. Dwyer, A. M. Pfeiffer D. E. Putnam, and D. E. Bauman. 2006. Response to conjugated linoleic acid in dairy cows differing in energy and protein status. J. Dairy Sci. 89:4620-4631.

DeLany, J. P., F. Blohm, A. A. Truett, J. A. Scimeca, and D. B. West. 1999. Conjugated linoleic acid rapidly reduces body fat content in mice without affecting energy intake. Am. J. Physiol. 276:R1172R1179.

Edmonson, A. J., I. J. Lean, L. D. Weaver, T. Farver, and G. Webster. 1989. A body condition scoring chart for Holstein dairy cows. J. Dairy Sci. 72:68-78.

GfE (Gesellschaft für Ernährungsphysiologie). 1991. Leitlinien für die Bestimmung der Verdaulichkeit von Rohnährstoffen an Wiederkäuern (Guidelines for determining the digestibility of crude nutrients in ruminants). J. Anim. Physiol. Anim. Nutr. (Berl.) $65: 229-234$.

GfE (Gesellschaft für Ernährungsphysiologie). 2001. Empfehlungen zur Energie- und Nährstoffversorgung der Milchkühe und Aufzuchtrinder (Recommendations of energy and nutrient supply for dairy cows and breeding cattle). DLG-Verlag, Frankfurt am Main, Germany.

Harvatine, K. J., J. W. Perfield, and D. E. Bauman. 2009. Expression of enzymes and key regulators of lipid synthesis is upregulated in adipose tissue during CLA-induced milk fat depression in dairy cows. J. Nutr. 139:849-854.

Jones, N. H. 1997. Finding the Area Under a Curve Using JMP and a Trapezoidal Rule. SAS Inst. Inc., Cary, NC.

Lee, C. Y., and D. M. Henricks. 1990. Comparisons of various acidic treatments of bovine serum on insulin-like growth factor-I immunoreactivity and binding activity. J. Endocrinol. 127:139-148.

Littell, R. C., P. R. Henry, and C. B. Ammerman. 1998. Statistical analysis of repeated measures data using SAS procedures. J. Anim. Sci. 76:1216-1231.

Lofgreen, G. P., and K. K. Otagaki. 1960. The net energy of blackstrap molasses for fattening steers as determined by a comparative slaughter technique. J. Anim. Sci. 19:392-403.

Lucy, M.C., H. Jiang, and Y. Kobayashi. 2001. Changes in the somatotropic axis associated with the initiation of lactation. J. Dairy Sci. 84(E Suppl.):E113-E119.

Medeiros, S. R., D. E. Oliveira, L. J. M. Aroeira, M. A. McGuire, D. E. Bauman, and D. P. D. Lanna. 2010. Effects of dietary supplementation of rumen-protected conjugated linoleic acid to grazing cows in early lactation. J. Dairy Sci. 93:1126-1137.

Moallem, U., H. Lehrer, M. Zachut, L. Livshitz, and S. Yacoby. 2010. Production performance and pattern of milk fat depression of high-yielding dairy cows supplemented with encapsulated conjugated linoleic acid. Animal 4:641-652.

Moe, P. W., H. F. Tyrrell, and W. P. Flatt. 1971. Energetics of body tissue mobilization. J. Dairy Sci. 54:548-553.

Odens, L. J., R. Burgos, M. Innocenti, M. J. VanBaale, and L. H. Baumgard. 2007. Effects of varying doses of supplemental conjugated linoleic acid on production and energetic variables during the transition period. J. Dairy Sci. 90:293-305.

Odens, L. J., R. Burgos, B. C. Pollard, M. L. Innocenti, S. H. Baker, S. R. Sanders, J. K. Kay, M. L. Rhoads, C. E. Moore, M. J. VanBaale, and L. H. Baumgard. 2006. Effects of varying CLA doses on production and bioenergetic variables during the transition period. J. Anim. Sci. 84(Suppl. 1):112. (Abstr.)

Pappritz, J., U. Meyer, R. Kramer, E. M. Weber, G. Jahreis, J. Rehage, G. Flachowsky, and S. Dänicke. 2011. Effects of long-term supplementation of dairy cow rations with rumen-protected conjugated linoleic acids (CLA) on performance, metabolic parameters and fatty acid distribution in milk fat. Arch. Anim. Nutr. 65:89-107.

Park, Y., K. J. Albright, W. Liu, J. M. Storkson, M. E. Cook, and M. W. Pariza. 1997. Effect of conjugated linoleic acid on body composition in mice. Lipids 32:853-858.

Pearce, J. 1983. Fatty acid synthesis in liver and adipose tissue. Proc. Nutr. Soc. 42:263-271.

Reid, J. T., G. H. Wellington, and H. O. Dunn. 1955. Some relationships among the major chemical components of the bovine body and their application to nutritional investigations. J. Dairy Sci. 38:1344-1359.

Sander, A. K., M. Piechotta, G. Schlamberger, H. Bollwein, M. Kaske, A. Sipka, and H. J. Schuberth. 2011. Ex vivo phagocytic overall performance of neutrophilic granulocytes and the relation to plasma insulin-like growth factor-I concentrations in dairy cows during the transition period. J. Dairy Sci. 94:1762-1771.

Saremi, B., H. Sauerwein, D. von Soosten, S. Dänicke, and M. Mielenz. 2011. Adiponectin system and peroxisome proliferator-activated receptor gamma2 (PPAR $\gamma 2)$ mRNA abundance in different bovine fat depots considering conjugated linoleic acids (CLA) or lactation stage related changes. J. Dairy Sci. 94(E-Suppl. 1):343. (Abstr.)

SAS Institute. 2004. SAS/STAT 9.1 User's guide. SAS Inst. Inc., Cary, NC.

Schiavon, S., F. Tagliapietra, M. Dal Maso, L. Bailoni, and G. Bittante. 2010. Effects of low-protein diets and rumen-protected conjugated linoleic acid on production and carcass traits of growing double-muscled Piemontese bulls. J. Anim. Sci. 88:3372-3383. 
Sinclair, L. A., W. M. P. B. Weerasinghe, R. C. Wilkinson, M. J. de Veth, and D. E. Bauman. 2010. A supplement containing trans-10, cis-12 conjugated linoleic acid reduces milk fat yield but does not alter organ weight or body fat deposition in lactating ewes. J. Nutr. 140:1949-1955.

Stangl, G. 2010. Das Zusammenspiel zwischen Proteinauf- und -Abbau-Neue Erkenntnisse zum Proteinturnover (The balance between protein synthesis and protein degradation-Novel insights into protein turnover). Übers. Tierernährung 38:1-32.

Staufenbiel, R. 1997. Konditionsbeurteilung von Milchkühen mit Hilfe der sonographischen Rückenfettdickenmessung (Evaluation of body condition in dairy cows by ultrasonographic measurement of back fat thickness). Prakt. Tierarzt 27:87-92.

Svanberg, E., H. Zachrisson, C. Ohlsson, B. M. Iresjo, and K. G. Lundholm. 1996. Role of insulin and IGF-1 in activation of muscle protein synthesis after oral feeding. Am. J. Physiol. 270:E614-E620.

Taylor, V. J., Z. Cheng, P. G. A. Pushpakumara, D. C. Wathes, and D. E. Beever. 2004. Relationships between the plasma concentrations of insulin-like growth factor-I in dairy cows and their fertility and milk yield. Vet. Rec. 155:583-588.

Tyrrell, H. F., and J. T. Reid. 1965. Prediction of energy value of cow's milk. J. Dairy Sci. 48:1215-1223.

van Knegsel, A. T. M., H. van den Brand, J. Dijkstra, W. M. van Straalen, M. J. W. Heetkamp, S. Tamminga, and B. Kemp. 2007. Dietary energy source in dairy cows in early lactation: Energy partitioning and milk composition. J. Dairy Sci. 90:1467-1476.

VDLUFA (Association of German Agricultural Analysis and Research Centers). 1993. Handbuch der Landwirtschaftlichen Versuchs- und Untersuchungsmethodik (VDLUFA-Methodenbuch). Vol. III. Die chemische Untersuchung von Futtermitteln. VDLUFA-Verlag, Darmstadt, Germany.
Vernon, R. G. 1980. Lipid metabolism in the adipose tissue of ruminant animals. Prog. Lipid Res. 19:23-106.

von Soosten, D., U. Meyer, E. M. Weber, J. Rehage, G. Flachowsky, and S. Dänicke. 2011. Effect of trans-10, cis-12 conjugated linoleic acid on performance, adipose depot weights and liver weight in early-lactation dairy cows. J. Dairy Sci. 94:2859-2870.

Wang, Y., and P. J. H. Jones. 2004. Dietary conjugated linoleic acid and body composition. Am. J. Clin. Nutr. 79:1153S-1158S.

Weber, W. J., C. R. Wallace, L. B. Hansen, H. Chester-Jones, and B. A. Crooker. 2007. Effects of genetic selection for milk yield on somatotropin, insulin-like growth factor-1, and placental lactogen in Holstein cows. J. Dairy Sci. 90:3314-3325.

Weiss, W. P., D. J. Wyatt, and T. R. McKelvey. 2008. Effect of feeding propionibacteria on milk production by early lactation dairy cows. J. Dairy Sci. 91:646-652.

Wenk, C., P. C. Colombani, J. van Milgen, and A. Lemme. 2001. Glossary: Terminology in animal and human energy metabolism. Pages 409-421 in Proc. 15th Symp. Energy Metab. Anim., Snekkersten, Denmark. A. Chwalibog and K. Jakobsen, ed. Wageningen Pers, Wageningen, the Netherlands.

West, D. B., F. Y. Blohm, A. A. Truettt, and J. P. DeLany. 2000 Conjugated linoleic acid persistently increases total energy expenditure in AKR/J mice without increasing uncoupling protein gene expression. J. Nutr. 130:2471-2477.

West, D. B., J. P. Delany, P. M. Camet, F. Blohm, A. A. Truett, and J. Scimeca. 1998. Effects of conjugated linoleic acid on body fat and energy metabolism in the mouse. Am. J. Physiol. 275:R667R672. 